\title{
Chemistry of hot springs along the Eastern Lau Spreading Center
}

Michael J. Mottl, Jeffrey Seewald, C. Geoffrey Wheat, Margaret K. Tivey, Peter J. Michael, Giora Proskurowski, Thomas M. McCollom, Eoghan Reeves, Jessica Sharkey, C.-F. You, L.-H. Chan*, and Thomas Pichler

*deceased

Final version of ms. W6987,

resubmitted to Geochimica et Cosmochimica Acta, December 8, 2010

\section{Affiliations:}

Mottl:

Dept. of Oceanography, University of Hawaii, 1000 Pope Road, Honolulu HI 96822 USA

Seewald, Tivey, Proskurowski, and Reeves:

Dept. of Marine Chemistry and Geochemistry, Woods Hole Oceanographic Institution, Woods Hole MA 02543 USA

Wheat:

Global Undersea Research Unit, P.O. Box 757220, University of Alaska, Fairbanks AK 99775 USA

Michael:

Dept. of Geosciences, The University of Tulsa, 800 S. Tucker Drive, Tulsa OK 74104 USA

McCollom:

Laboratory for Atmospheric and Space Physics, University of Colorado, 1234 Innovation Drive, Boulder CO 80303

Sharkey: 
Global Undersea Research Unit, P.O. Box 757220, University of Alaska, Fairbanks AK 99775 USA

You:

Dept. of Earth Sciences, National Cheng Kung University, No. 1 University Road, Tainan City 701, Taiwan

*Chan:

Dept. of Geology and Geophysics, Louisiana State University, Baton Rouge LA 70803

Pichler:

Fachbereich Geowissenschaften, University of Bremen, Postfach 330 440, 28334 Bremen, Germany 


\section{Abstract}

The Eastern Lau Spreading Center (ELSC) is the southernmost part of the back-arc spreading axis in the Lau Basin, west of the Tonga trench and the active Tofua volcanic arc. Over its 397-km length it exhibits large and systematic changes in spreading rate, magmatic/tectonic processes, and proximity to the volcanic arc. In 2005 we collected 81 samples of vent water from six hydrothermal fields along the ELSC. The chemistry of these waters varies both within and between vent fields, in response to changes in substrate composition, temperature and pressure, $\mathrm{pH}$, water/rock ratio, and input from magmatic gases and subducted sediment. Hot-spring temperatures range from $229^{\circ}$ to $363^{\circ} \mathrm{C}$ at the five northernmost fields, with a general decrease to the south that is reversed at the Mariner field. The southernmost field, Vai Lili, emitted water at up to $334^{\circ} \mathrm{C}$ in 1989 but had a maximum venting temperature of only $121^{\circ} \mathrm{C}$ in 2005 , due to waning activity and admixture of bottom seawater into the subseafloor plumbing system. Chloride varies both within fields and from one field to another, from a low of $528 \mathrm{mmol} / \mathrm{kg}$ to a high of $656 \mathrm{mmol} / \mathrm{kg}$, and may be enriched by phase separation and/or leaching of $\mathrm{Cl}$ from the rock. Concentrations of the soluble elements $\mathrm{K}, \mathrm{Rb}, \mathrm{Cs}$, and $\mathrm{B}$ likewise increase southward as the volcanic substrate becomes more silica-rich, especially on the Valu Fa Ridge. Iodine and $\delta^{7} \mathrm{Li}$ increase southward, and $\delta^{11} \mathrm{~B}$ decreases as $\mathrm{B}$ increases, apparently in response to increased input from subducted sediment as the arc is approached. Species that decrease southward as temperature falls are $\mathrm{Si}, \mathrm{H}_{2} \mathrm{~S}, \mathrm{Li}, \mathrm{Na} / \mathrm{Cl}, \mathrm{Fe}, \mathrm{Mn}$, and ${ }^{87} \mathrm{Sr} /{ }^{86} \mathrm{Sr}$, whereas $\mathrm{pH}$, alkalinity, $\mathrm{Ca}$, and $\mathrm{Sr}$ increase. Oxygen isotopes indicate a higher water/rock ratio in the three systems on Valu Fa Ridge, consistent with higher porosity in more felsic volcanic rocks. Vent waters at the Mariner vent field on the Valu Fa Ridge are significantly hotter, more acid and metal-rich, less saline, and richer in dissolved gases and other volatiles, including $\mathrm{H}_{2} \mathrm{~S}, \mathrm{CO}_{2}$, and $\mathrm{F}$, than the other vent fields, consistent with input of magmatic gases. The large variations in geologic and geophysical parameters produced by back-arc spreading along the ELSC, which exceed those along mid-ocean ridge spreading axes, produce similar large variations in the composition of vent waters, and thus provide new insights into the processes that control the chemistry of submarine hot springs. 


\section{INTRODUCTION}

Seafloor spreading in back-arc basins contrasts significantly with that along mid-ocean ridges in the associated mantle dynamics, structure and composition of the crust, seafloor morphology, and related hydrothermal springs and deposits. Back-arc crust may be more closely analogous to ophiolites, and hydrothermal sulfide deposits formed there are more closely analogous to massive sulfide ore deposits that are exploited on land (e.g., Franklin et al., 1981; Sawkins, 1990; Hannington et al., 2005). Back-arc spreading axes provide critical geographic and genetic links in the global distribution of hydrothermal vent organisms, especially in the South and Western Pacific. For these reasons a back-arc spreading site was chosen for long-term interdisciplinary study by U.S. National Science Foundation's RIDGE 2000 (R2K) program as one of its first three Integrated Studies Sites (ISS). The targeted backarc for R2K is the Eastern Lau Spreading Center (ELSC) in the Lau Basin, west of the Tonga volcanic arc (Fig. 1). The ELSC is a first-order ridge segment that extends $397 \mathrm{~km}$ from the large non-transform offset near $19^{\circ} 20^{\prime} \mathrm{S}$ to the propagating southern tip of the Valu Fa Ridge (VFR) at about $22^{\circ} 45^{\prime} \mathrm{S}$, where the basin narrows toward the arc. The ELSC displays large and systematic variation over this distance in spreading rate, magma source and lava chemistry, axial depth and morphology, melt lens characteristics, crustal structure, and proximity to arc magma sources and to the subducting slab at depth.

The VFR, which comprises the southernmost segments of the ELSC south of the nontransform offset near $21^{\circ} 26^{\prime} \mathrm{S}$ and extending to $22^{\circ} 45^{\prime} \mathrm{S}$, is the shallowest part of the ELSC, despite having the slowest spreading rate and the deepest melt lens (Jacobs et al., 2007). It is shallowest because it is closest to the active Tofua arc and presumably has the highest magma supply rate (Martinez et al., 2006). Prior to the inception of R2K, the three hydrothermal fields known from the ELSC were all on the VFR, and none of them had been visited since 1989: the inactive White Church field, the low-temperature Hine Hina field with abundant macrofauna, and the high-temperature Vai Lili field with sparse organisms (Fouquet et al., 1993; Herzig et al., 1993). The 1989 data showed these fields to be unusual compared with hot springs from normal mid-ocean ridges: the high-temperature $\left(334^{\circ} \mathrm{C}\right)$ Vai Lili field near $22^{\circ} 15^{\prime} \mathrm{S}$ displayed the lowest $\mathrm{pH}$ (2.0) and the highest concentrations of $\mathrm{K}, \mathrm{Mn}, \mathrm{Zn}, \mathrm{Cd}, \mathrm{Pb}, \mathrm{As}$, and rare-earth elements ever 
measured in a deep-sea hot spring. In 1989 the Vai Lili springs also had higher $\mathrm{Cu}, \mathrm{B}, \mathrm{Rb}$, and Cs than most mid-ocean ridge hydrothermal vents.

R2K has sponsored a series of cruises to the Lau Basin since 2004. Cruise 1 located 29 hydrothermal plume signatures in the water column along the ELSC (Baker et al., 2006; Martinez et al., 2006). Cruise 2 used the Autonomous Benthic Explorer (ABE) to locate, map, and photograph vent fields associated with these plumes. Three vent fields (Kilo Moana, TowCam, and ABE) were located and imaged in detail (German et al., 2008). A fourth field, Mariner, was discovered by Japanese scientists (Ishibashi et al., 2006), in part through use of information provided by investigators on Cruise 2. Our Cruise 3, TUIM05MV on the $R / V$ Melville in April-May, 2005, located a fifth new vent field, Tui Malila, and visited all five as well as the Vai Lili field with the ROV Jason, mapping them in detail (Ferrini et al., 2008) and sampling them for igneous substrate, vent deposits, macro- and microbiota, and spring water.

Here we report results of shipboard and shorebased analyses of 81 spring water samples collected from 43 vents in the six vent fields. Our immediate objective is to describe the compositions of the vent waters and place them in the context of the variable geologic settings present along the ELSC, in order to identify factors that affect the compositions of the hot springs. Our larger objective is to determine the linkages among the regional and fine-scale geology, the distribution and types of hydrothermal venting and resulting deposits, and the biological communities that have evolved in response to the unusual and contrasting gradients in spreading rate, magma supply, lava chemistry, and crustal structure found along the ELSC. A clear understanding of these gradients, including the full range of variables and their interrelationships, their upper and lower limits and their patterns of variation, whether uniform in slope, stepwise or variable in some other way, is an essential prerequisite to understanding the interplay among magmatic, tectonic, hydrothermal, and biological processes along the Lau backarc spreading axis.

\section{GEOLOGIC SETTING}

The ELSC encompasses among the most striking and pronounced gradients in fundamental properties of any similar length of spreading axis on the globe (Martinez and Taylor, 2002; Martinez et al., 2006). Accretionary variables such as ridge cross-sectional area 
and axial depth, moreover, are anti-correlated with spreading rate, in contrast with the usual positive correlations along the mid-ocean ridge. As the full spreading rate decreases from 97 to $39 \mathrm{~mm} / \mathrm{yr}$ from north to south along the ELSC, axial depth shows a pronounced decrease from 3000 to 1600 mbsl (Fig. 2) rather than the usual increase, and axial cross-sectional area increases southward (Table 1), from an axial valley with split volcanoes, through transitional, lowamplitude morphology, to the steeply-sided axial ridge of the VFR (Martinez et al., 2006). Here, the master variable appears to be proximity to the active Tofua arc, which is $110 \mathrm{~km}$ east of the ELSC at the northern end but only $40 \mathrm{~km}$ away at the southern end where the VFR is propagating into old arc crust. Increasing subduction influence appears to enhance magma supply and to overwhelm the "normal" controls imposed by spreading rate variation. Over the same distance north to south the dominant crustal lithology changes from depleted tholeiitic back-arc basin basalt (BABB) with Indian-type isotopic ratios along the northern ELSC, to arclike basaltic andesite, andesite, and rhyodacite with Pacific-type isotopic ratios along the VFR closer to the arc (Martinez and Taylor, 2002). The southward increase in the silica content of magmas would be accompanied by an increase in their volatile content, porosity, and viscosity, which is reflected in the change in volcanic morphology (Table 1; Jacobs et al., 2007).

Gradients in other parameters, however, seem to be influenced by both spreading rate and subduction influence, as estimated by proximity to the arc. The seismically imaged magma-lens reflector deepens southward as spreading slows and the arc is approached (Fig. 2; Jacobs et al., 2007). North of the ELSC the Central Lau Spreading Center (CLSC), opening at 87-90 mm/yr, displays a shallow (1.1-2.0 km deep) reflector from $18^{\circ} 20^{\prime}$ to $19^{\circ} 07^{\prime} \mathrm{S}$, typical of magma-lens depths along the fast-spreading East Pacific Rise. Except for an isolated melt sill north of the Kilo Moana vent field, no melt-lens reflectors have been detected along the northernmost $70 \mathrm{~km}$ of the ELSC, even though this section has the fastest opening rates of $97-77 \mathrm{~mm} / \mathrm{yr}$. There is a continuous or nearly continuous reflector southward from $20^{\circ} 30^{\prime} \mathrm{S}$, however, that deepens abruptly, from 2.0-2.4 km north of the VFR, to 2.3-3.3 km on the slower-spreading but inflated VFR. The ELSC has a correspondingly thicker and slower layer 2A than the CLSC, and this thickness is greatest and seismic velocity slowest along the VFR (Table 1). Moreover, along the ELSC the layer 2A thickness has already reached its maximum at the axis, and shows no further thickening with crustal age, as occurs along the CLSC and most mid-ocean ridges. Overall crustal thickness increases southward along axis as well, from about $5.5 \mathrm{~km}$ at $18^{\circ} 33^{\prime} \mathrm{S}$ 
(Crawford et al., 2003) to as much as $9.0 \mathrm{~km}$ on the VFR (Turner et al., 1999). The thinnest crust along the ELSC is found north of $20^{\circ} 30^{\prime} \mathrm{S}$ where there is no magma-lens reflector. These changes contrast with those in response to increasing magma supply along the near-constant (45$56 \mathrm{~mm} / \mathrm{yr}$ ) intermediate spreading rate Galapagos Spreading Center (GSC) as it approaches the Galapagos hotspot (Detrick et al., 2002). As magma supply increases along the GSC, the magma lens becomes shallower, layer 2 a becomes thinner, but overall crustal thickness increases. The crustal structure of the ELSC lies well outside that of normal crust formed along any mid-ocean ridge (Jacobs et al., 2007).

\subsection{Geologic setting of vent fields and vents}

The six vent fields we sampled for hot spring waters are separated by distances of 4 to $142 \mathrm{~km}$ along the ELSC. Differences in geological and geophysical parameters at each vent field are summarized in Table 1 and Figure 2. The northernmost fields, Kilo Moana and TowCam, are located at similar depths of $2620 \mathrm{~m}$ and $2700 \mathrm{~m}$, respectively. Hydrothermal activity in these fields is associated with faults and fissures that crosscut broad, low-relief volcanic domes and pillow and lobate flows (Ferrini et al., 2008). Igneous rocks recovered from these two fields are basaltic in composition and exhibit small-scale chemical heterogeneities (Escrig et al., 2009). Hot water discharges locally from edifices that stand $\sim 3$ to $16 \mathrm{~m}$ tall and are $\sim 2$ to $5 \mathrm{~m}$ in diameter and, in the southern part of the TowCam vent field, from an $\sim 8 \mathrm{~m}$ diameter mound capped with small pipe-like chimneys. Warm, diffuse flow discharges from the basaltic substrate near the base of edifices at the Kilo Moana vent field, and both near and far from edifices at the TowCam field (Ferrini et al., 2008). The edifices are composed of coalesced pipes, some with cactus-like protrusions (Tivey et al., 2005). Hot water exits from both open-conduit "black smokers" and from "diffusers", "white smoker" spires that lack any large open conduits.

Farther south, the ABE and Tui Malila vent fields are hosted in terrain that exhibits more variable and complex volcanic morphology. Volcanic domes within and near these vent fields have higher aspect ratios (height to width) than those near the northern fields. Pillows, aa-type lavas, and distinct finger-like flows are also present, likely reflecting higher lava viscosity (Ferrini et al., 2008). Igneous rocks recovered from near the ABE vent field are basaltic andesites, with all lavas at or above saturation with $\mathrm{H}_{2} \mathrm{O}$. A plot of the ratio of $\mathrm{Ba} / \mathrm{La}$, both highly 
incompatible elements, from north to south exhibits a pronounced step to higher values near the $\mathrm{ABE}$ vent field, reflecting a step-like change to a more andesitic composition and greater subduction influence (Fig. 3; Escrig et al., 2009). The silica content of lavas recovered in 1989 from near the latitude of the Tui Malila vent field indicates rocks of basaltic andesite composition (Fouquet et al., 1993). The ABE and Tui Malila vent fields are located at significantly different depths of $2140 \mathrm{~m}$ and $1880 \mathrm{~m}$, respectively, on two different spreading segments, which differ in their large scale morphology from rounded at the latitude of ABE to peaked at that of Tui Malila (Martinez et al., 2006). Both fields, however, are hosted on a basaltic andesite substrate, both exhibit aa-type lavas and finger-like flows, and both are crosscut by faults that trend N-S to NE-SW, with throws of 4 to $20 \mathrm{~m}$, down-dropped to the east. Columnar jointing was also observed in both vent fields along stepped fault scarps (Ferrini et al., 2008). Hot water exits both open conduit "black smokers" and "diffusers" from vents that stand 3 to $8 \mathrm{~m}$ tall and have multiple spires, or from small ( $<1 \mathrm{~m}$ tall) chimneys; in addition, slightly cooler waters pool beneath flanges that protrude from either fault scarps or sulfide-rich edifices (Ferrini et al., 2008).

Farthest south, at the Mariner and Vai Lili vent fields on the Valu Fa Ridge, south of the overlapping spreading center at $22^{\circ} 12^{\prime} \mathrm{S}$, the volcanic morphology is dominated by small (tens of meters diameter) domes, identifiable flow fronts, and an absence of crosscutting faults or fissures (except for a single identified fault within the Vai Lili vent field; Ferrini et al., 2008). Volcanic relief is greater than that within vent fields to the north, and aa-type lava flows dominate, consistent with more viscous lavas (Ferrini et al., 2008). The silica content of lavas recovered in 1989 from near the latitude of these vent fields indicates rocks of predominantly basalticandesite and andesite composition, with some basalts and dacites also recovered (Fouquet et al., 1993). At the Mariner vent field, hot water discharges from the base and sides of tall (<10 to $27 \mathrm{~m}$ ), narrow (3 to $4 \mathrm{~m}$ diameter) pinnacles, while lower temperature water emanates from tabular, squat edifices (Ferrini et al., 2008). While temperatures as high as $334^{\circ} \mathrm{C}$ were measured at the Vai Lili vent field in 1989 (Fouquet et al., 1993), no high-temperature venting was observed there in 2005 . The highest temperature $\left(121^{\circ} \mathrm{C}\right)$ water sampled in 2005 was from a pool beneath a marcasite-lined flange. Cooler, clear, focused fluids $\left(70^{\circ} \mathrm{C}\right)$ were sampled from an Feoxide-rich chimney. Lower temperature $\left(40^{\circ} \mathrm{C}\right)$ diffuse waters exiting directly from the igneous substrate, and associated with thick microbial mats, were also sampled. 


\section{METHODS}

81 spring water samples were collected by the ROV Jason in two types of bottles: 13 in conventional 750-mL Ti-syringe samplers (Edmond et al., 1992) and 68 in 90-mL isobaric gastight samplers (Seewald et al., 2002). For the gas-tight samplers, temperature was measured continuously over the 1-2 minutes during which the sampler filled. For the Ti-syringes, temperature was measured using the Jason probe immediately prior to sampling. In both cases we report the maximum temperature measured. Dives were variable in duration so that 5-23 hours typically passed between sampling on the seafloor and recovery of samples on deck. Once in hand samples were processed and analyzed as quickly as possible, although for a limited number of samples 1-2 days passed before the samples could be processed due to malfunction of the shipboard gas chromatographs.

Samples were filtered through $0.45 \mu$ m nylon filters and analyzed onboard ship using IAPSO seawater as a standard (with estimated $1 \sigma$ precisions in parentheses), for $\mathrm{pH}$ ( \pm 0.05 units) by ion-specific electrode, alkalinity $( \pm 2 \%)$ by potentiometric Gran titration with $0.1 \mathrm{~N} \mathrm{HCl}$, chlorinity $( \pm 0.3 \%$ ) (= chloride + bromide) by automated electrochemical titration with $0.1 \mathrm{M}$ silver nitrate, $\mathrm{Ca}( \pm 0.5 \%)$ by automated titration with 0.01M EGTA using an Orion Model 93-20 calcium ion-specific electrode, and $\mathrm{Mg}( \pm 0.4 \%)$ by colorimetric titration with $0.03 \mathrm{M}$ EDTA for total alkaline earths (Gieskes et al., 1991). Total aqueous sulfide $\left(\Sigma \mathrm{H}_{2} \mathrm{~S}\right)$ was quantitatively precipitated as $\mathrm{Ag}_{2} \mathrm{~S}$ onboard ship so that concentrations ( $\pm 4 \%$ ) could be calculated following gravimetric measurement in a shore-based laboratory at Woods Hole. Also analyzed shipboard, using prepared standards, were dissolved sulfide $( \pm 5 \%)$ by colorimetry using methylene blue, fluoride $( \pm 2 \%$ ) by Orion Model 94-09 ion-specific electrode on solutions buffered with TISAB II and corrected for Mg concentration, sulfate $( \pm 2 \%)$ and bromide $( \pm 4 \%)$ by ion chromatography, and $\mathrm{H}_{2}$, methane, and $\mathrm{CO}$ by gas chromatography. Analysis of aqueous $\mathrm{Mg}$ concentration $( \pm 2 \%)$ was repeated onshore by inductively-coupled plasma atomic-emission spectrometry (ICP-AES). The shorebased gravimetric analyses for dissolved sulfide are reported here, as they proved to be more accurate and precise. The shorebased analyses for $\mathrm{Mg}$ are reported only for those samples in which the concentration was $<5 \mathrm{mmol} / \mathrm{kg}$, and thus difficult to measure accurately by the more 
precise colorimetric titration. Where analyses were performed volumetrically, we converted the results from mmol/liter to $\mathrm{mmol} / \mathrm{kg}$ using a nominal density of 1.0243 .

Elements measured in shorebased laboratories include Li, Na, K, Sr, B, Si, Mn, and Fe by ICP-AES (C.G. Wheat); and Al, P, I, Rb, and Cs by ICP-mass-spectrometry (ICP-MS) (C.G. Wheat and C.-F. You). As, Ge, Se, Sb, and Te were measured by hydride generation followed by ICP-AES (T. Pichler). The abundances of Mn and Fe were determined in solids precipitated from the solutions in the samplers subsequent to sampling, as well as in the solutions themselves. The reported concentrations of $\mathrm{Mn}$ and Fe include the amount precipitated in the samplers. Reported concentrations for $\mathrm{Na}$ were calculated from charge balance, as these values agree approximately with those measured by ICP-AES but are much more precise. Dissolved inorganic carbon (DIC: nearly all $\mathrm{CO}_{2}$ at low $\mathrm{pH}$ ) was analyzed at Woods Hole by gas chromatography (Proskurowsi et al., 2007). Isotopes were analyzed by mass spectrometry for $\mathrm{O}$ and $\mathrm{H}$ in $\mathrm{H}_{2} \mathrm{O}$ at the SIRFER laboratory of the University of Utah, following evaporative separation to remove dissolved salts; Li at Louisiana State University (L.H. Chan), B at National Cheng Kung University in Taiwan (C.-F. You), and Sr at the University of Hawaii (M.J. Mottl); and $\mathrm{S}$ in $\mathrm{H}_{2} \mathrm{~S}$ and $\mathrm{C}$ in methane and DIC at Woods Hole. Carbon and helium isotopic results have been reported by Proskurowsi et al. (2007).

\section{RESULTS}

We sampled 43 different vents from the six vent fields and collected 81 spring water samples, 55 of which contained $<10 \mathrm{mmol} / \mathrm{kg} \mathrm{Mg}$ (and $52<6 \mathrm{mmol} / \mathrm{kg}$ ). Four samples from three vents are not plotted in Figures 4 and 6-12 because they had $>49.8 \mathrm{mmol} / \mathrm{kg} \mathrm{Mg}$ and are estimated to consist of $>94 \%$ bottom seawater. The composition of hot springs within the six vent fields varies both within a single field and from one field to another. To illustrate the intrafield variations we have plotted the composition of each vent against distance from north to south along the long axis of the vent field, which runs NE-SW, subparallel to the ridge axis, for every field except Kilo Moana, which runs NNW-SSE (Figs. 4, 6-12, and Tables 2 and 3). We have plotted the zero-Mg end-member concentrations for each vent, as is the usual practice, by extrapolating from the composition of bottom seawater collected at each vent field, through the $\mathrm{Mg}$ concentration measured in the samples from a given vent. 


\subsection{Temperature}

The five northernmost fields vented low-Mg $(<9 \mathrm{mmol} / \mathrm{kg})$ fluids ranging in temperature from $229^{\circ}$ to $363^{\circ} \mathrm{C}$ (Fig. 2 and Table 2). The four northern vent fields show a slight decline in temperature from north to south (Fig. 4), but this trend is reversed at Mariner, which has the largest range in temperature for low-Mg springs. With only three exceptions, the low-

temperature waters when extrapolated to zero $\mathrm{Mg}$ yielded temperatures within the same range as the high-temperature vents from the same field, demonstrating that they were cooled mainly by mixing with bottom seawater, introduced just prior to sampling, either within the edifice prior to venting or by entrainment of ambient seawater during sampling. At the Vai Lili field in 2005 we found a maximum temperature of only $121^{\circ} \mathrm{C}$, compared with $334^{\circ} \mathrm{C}$ measured in 1989 (Fouquet et al., 1993), indicating that hydrothermal activity is waning at Vai Lili. The Vai Lili springs showed uniformly high $\mathrm{Mg}$ concentrations of 14-46 mmol/kg, suggesting that extensive mixing with unreacted seawater in the shallow subsurface was a major factor in lowering their temperature. Correcting for subseafloor mixing by extrapolating to zero $\mathrm{Mg}$ (Fig. 4) raises the $70^{\circ}$ and $121^{\circ} \mathrm{C}$ springs at Vai Lili to $95 \pm 1^{\circ}$ and $189 \pm 3^{\circ} \mathrm{C}$, respectively (and the $40^{\circ} \mathrm{C}$ spring to $270 \pm 20^{\circ} \mathrm{C}$, although substantial uncertainty is associated with this value due to the large extrapolation, from a measured concentration of $44.8 \mathrm{mmol} / \mathrm{kg} \mathrm{Mg}$ ).

\section{2. $\mathrm{Mg}$ and Sulfate}

As is typical for high-temperature springs of seawater origin, $\mathrm{Mg}$ and sulfate decrease together linearly from their concentrations in seawater to nearly zero (Fig. 5). Negative deviations from a linear decrease could result from precipitation of anhydrite on mixing of spring water with seawater, as occurs within high-temperature chimneys. Positive deviations could result from dissolution by cooler solutions of anhydrite precipitated earlier in the subsurface, or from dissolution within the samplers of chimney particles that may have been entrained during sampling.

\section{3. $\mathrm{pH}$, Alkalinity, $\mathrm{Fe}, \mathrm{Mn}, \mathrm{H}_{2} \mathrm{~S}$, and $\mathrm{Si}$}


Alkalinity (not shown) and pH generally increase southward from Kilo Moana to Vai Lili, except for sharply decreased values at Mariner (Fig. 6). Mariner yielded a minimum pH of 2.5, similar to the value of 2 measured in the $334^{\circ} \mathrm{C}$ spring at Vai Lili in 1989 but much lower than the 5.2 at Vai Lili in 2005. The negative values for alkalinity typically measured (Table 2) denote the presence of mineral acidity. The patterns of variation in Fe and $\mathrm{Mn}$ from field to field are almost exact mirror images of that for $\mathrm{pH}$ (Fig. 6), such that higher concentrations of these metals correlate with lower $\mathrm{pH}$. The only discrepancies are for Fe at Vai Lili in 1989, which is lower than it would be if Fe mirrored pH perfectly, and Mn at Vai Lili in 2005. As Vai Lili cooled from $334^{\circ}$ to $121^{\circ} \mathrm{C}$ between 1989 and 2005, $\mathrm{pH}$ rose from 2.0 to 5.3 and Fe fell 10-20fold, whereas Mn fell only 3-5-fold. The much smaller drop in Mn is consistent with our interpretation in section 4.1 that the major cause of cooling at Vai Lili is mixing with seawater in the shallow subsurface, a process that would efficiently precipitate Fe as sulfide minerals, but leave Mn largely in solution.

$\mathrm{Si}$ and $\mathrm{H}_{2} \mathrm{~S}$ show similar patterns from one field to the next (Figs. 4 and 6), decreasing southward from Kilo Moana to Tui Malila, increasing to Mariner, and then decreasing sharply to Vai Lili. These chemical species closely track temperature (Fig. 4).

\subsection{Chlorinity and $\mathrm{Br}$}

Chlorinity varies both within fields and from one field to another, from a low of 528 $\mathrm{mmol} / \mathrm{kg}$ at TowCam to a high of $656 \mathrm{mmol} / \mathrm{kg}$ at Tui Malila (Fig.7). Nearly all samples are saltier than the ambient bottom seawater, and only TowCam has an average chlorinity (536 \pm 10 $\mathrm{mmol} / \mathrm{kg}$ ) that is similar to that of bottom seawater $(538 \mathrm{mmol} / \mathrm{kg})$. Mariner shows the largest range in chlorinity, from 531 to $626 \mathrm{mmol} / \mathrm{kg}$. The range at $\mathrm{ABE}$ is almost as large, with chlorinity increasing systematically from north to south. Chlorinity at TowCam and Tui Malila also increases southward, whereas at Kilo Moana it increases northward.

Ratios of measured Br/chlorinity average $1.56 \pm 0.05(1 \sigma)$ for the 81 samples, vs. $1.54 \pm$ 0.03 for seawater (accounting for $\pm 4 \%$ analytical uncertainty for $\mathrm{Br}$ ). The three northern fields average $1.57 \pm 0.05$. The three southern fields, those on the VFR, average $1.54 \pm 0.04$ and thus on average are indistinguishable from seawater. 


\subsection{Alkali and Alkaline Earth Elements}

Concentrations of Li and especially Na follow those of chlorinity (Fig. 7). Plotting the ratios of $\mathrm{Li}$ (not shown) and $\mathrm{Na}$ to chlorinity (Fig. 7) eliminates the effect of variation in the major anion and shows that these elements decrease southward, except for a strong reversal in this trend for $\mathrm{Na}$ at Vai Lili. Na thus shows a strong minimum at Mariner, which has among the lowest $\mathrm{Na}$ /chlorinity ratios ever measured in a seafloor hot spring.

In contrast with $\mathrm{Li}$ and $\mathrm{Na}$, the patterns for the heavier alkalies $\mathrm{K}, \mathrm{Rb}$, and $\mathrm{Cs}$ are not so strongly affected by chlorinity (Fig. 8). Plotting these elements as ratios to chlorinity (not shown) removes most of the intrafield variation at $\mathrm{ABE}$ and Mariner, showing that it results mainly from variation in chlorinity. Concentrations of $\mathrm{K}, \mathrm{Rb}$, and $\mathrm{Cs}$ are similar at the two northernmost, basalt-hosted sites Kilo Moana and TowCam and are the only elements we measured (along with possibly B and F) for which this is the case. These elements trend in the opposite direction from $\mathrm{Li}$ and $\mathrm{Na}$, increasing southward to a strong maximum at Tui Malila before decreasing slightly to Mariner and Vai Lili.

The field-to-field pattern for $\mathrm{Ca}$ and $\mathrm{Sr}$ (Fig. 9) resembles that for K, Rb, and Cs, as both sets of elements increase southward to a maximum at Tui Malila. The chief difference is that $\mathrm{Ca}$ and $\mathrm{Sr}$ are higher at TowCam than at ABE or Kilo Moana. This pattern changes dramatically for $\mathrm{Ca}$, however, when it is plotted as the ratio to chlorinity (not shown): TowCam has the highest $\mathrm{Ca} /$ chlorinity ratios, and $\mathrm{ABE}$, Tui Malila, and Mariner are nearly identical to each other. The $\mathrm{Sr}$ isotopic ratio (Fig. 9) is more or less inversely related to the $\mathrm{Sr}$ concentration. It also shows a nearly identical pattern to temperature, $\mathrm{Si}$, and $\mathrm{H}_{2} \mathrm{~S}$, except for a sharp increase at Vai Lili rather than a decrease. This difference at Vai Lili represents a shift toward the value in seawater for all three species, however, to very low values for $\mathrm{H}_{2} \mathrm{~S}$ and $\mathrm{Si}$ and a higher value for the $\mathrm{Sr}$ isotopic ratio, so in this sense the three patterns are similar.

\subsection{Fluoride, $\mathrm{CO}_{2}$, I, and $\mathrm{B}$, and the Isotopes of $\mathrm{Li}, \mathrm{B}, \mathrm{O}$, and $\mathrm{H}$}

Fluoride (Fig. 10) is depleted relative to seawater in the four northernmost vent fields, highly enriched at Mariner, and then highly depleted at Vai Lili. The pattern for $\mathrm{CO}_{2}$ (Fig. 10) is 
nearly identical, except that all samples are enriched in $\mathrm{CO}_{2}$ relative to the concentration of dissolved inorganic carbon (DIC) in seawater of $2.3 \mathrm{mmol} / \mathrm{kg}$.

Iodine (Fig. 11) increases steadily southward from Kilo Moana to Mariner and then falls off at Vai Lili. The isotopic composition of dissolved Li (Fig. 11) likewise increases southward, all the way to Vai Lili. The resemblance between these two species extends to intra- as well as interfield variation. Whereas all samples are highly enriched in I relative to seawater, they are all depleted in ${ }^{7} \mathrm{Li}$ compared with the $\delta^{7} \mathrm{Li}$ value of about $+32 \%$ in bottom seawater (Tomascak, 2004).

Like I and $\delta^{7} \mathrm{Li}, \mathrm{B}$ (Fig. 11) increase southward from Kilo Moana to Mariner and then decrease at Vai Lili. This contrasts with $\delta^{11} \mathrm{~B}$, which decreases steadily southward (Fig. 11). All samples are substantially enriched in B relative to seawater and there is significant variation within each vent field. All samples have lower $\delta^{11} \mathrm{~B}$ than does seawater.

The end-member oxygen isotopic ratio (Fig. 12) is significantly higher in the three northern vent fields $\left(\delta^{18} \mathrm{O}=+0.79 \pm 0.19 \%\right.$ o, $1 \sigma$, based on individual samples $)$ than in the three southern fields $\left(\delta^{18} \mathrm{O}=+0.28 \pm 0.10 \%\right.$ ). In spite of a large range at some vent fields, especially Kilo Moana $\left(\delta^{18} \mathrm{O}=+0.39\right.$ to $+1.08 \%$ ), there is almost no overlap between the northern fields and the southern fields. All samples are slightly enriched in ${ }^{18} \mathrm{O}$ compared with bottom seawater.

The end-member hydrogen isotopic ratio (Fig. 12) is largely trendless from field to field, as the average at Tui Malila is identical with that at Kilo Moana at $\delta \mathrm{D}=-0.95 \%$ (based on individual samples). Mariner is only slightly heavier at $+0.01 \pm 1.2 \%(1 \sigma)$. $\delta \mathrm{D}$ ranges by several per mil within each field, with the largest range of -4.1 to +2.2 again at Kilo Moana; in fact, this range encompasses the entire range at the five northern vent fields. Nearly all samples are heavier than bottom seawater, and only Vai Lili has an average $\delta \mathrm{D}(-5.1 \pm 1.8 \%)$ that is lighter.

\subsection{Other Elements}

Ge and As (not shown) trend upward from Kilo Moana in the north to Tui Malila in the south, to maximum concentrations of 0.27 and $2.1 \mathrm{umol} / \mathrm{kg}$, respectively, and then drop at Mariner. Our maximum As concentration is far lower than the 6 to $11 \mu \mathrm{mol} / \mathrm{kg}$ measured shipboard at Vai Lili in 1989 (Fouquet et al., 1993). P, Se, Sb, and Te were also measured, with maximum concentrations of $25 \mu \mathrm{mol} / \mathrm{kg}$ and 15,28 , and $<8 \mathrm{nmol} / \mathrm{kg}$, respectively, but the results 
are scattered and trendless. We have not plotted these data because they were mistakenly measured on unacidified samples, are highly scattered, and probably do not represent the real concentrations in the springs because of precipitation subsequent to collection.

Al was measured on 18 samples from the six vent fields. The Mariner field yielded concentrations of $<1,8$, and $11 \mu \mathrm{mol} / \mathrm{kg}$, and the $\mathrm{ABE}$ field concentrations of $<1,<1,4$, and 4 $\mu \mathrm{mol} / \mathrm{kg}$. The other 11 samples were below our detection limit of $1 \mu \mathrm{mol} / \mathrm{kg}$. The higher concentration at Mariner is to be expected from its lower $\mathrm{pH}$.

\section{DISCUSSION}

The six vent fields sampled during this study are spread along $246 \mathrm{~km}$ of the ELSC from Kilo Moana in the north to Vai Lili in the south (Fig. 1). Owing to the southward convergence of the ELSC and the Tofua arc volcanic front (Fig. 1), there is a systematic increase in the influence of the arc and subducted slab on the composition and structure of the ridge-crest from north to south along this distance. With respect to depth, igneous substrate, and large-scale magmatic/tectonic parameters the six vent fields fall into three groups (Table 1): 1) Kilo Moana and TowCam located on the northern ELSC are $29 \mathrm{~km}$ apart and lie on depleted tholeiitic backarc basin basalt (BABB) at 2620-2730 $\mathrm{m}$ depth, where the spreading rate is fast, the crust is relatively thin, the axis is a trough, a magma lens is absent, and faults are abundant, large, and widely spaced; 2) the ABE field, located $50 \mathrm{~km}$ south of TowCam on the central ELSC, lies on basaltic andesites at an intermediate depth of $\sim 2150 \mathrm{~m}$, where spreading rate and crustal thickness have intermediate values, the axis is flat, there is a moderately deep magma lens (though not directly beneath the vent field), and km-scale faulting is less abundant (although faults and fissures proved to be abundant at a vent field scale (Ferrini et al., 2008)); and 3) the three southern fields lie on basaltic andesite and more felsic rocks along $25 \mathrm{~km}$ of the VFR at 1710-1920 m depth, where the spreading rate is much slower, the crust is thick, the axis is a peaked ridge, and the magma lens is deep (Martinez et al., 2006). In the northern part of the VFR near Tui Malila faults are common but are small and closely spaced (Martinez et al., 2006); at the vent-field scale, in fact, Tui Malila resembles ABE. By contrast, except for a single eruptive fissure seen at Vai Lili, surficial faults and fissures were not obseved at the two southernmost fields, where hydrothermal circulation is likely controlled by volcanic structures and plumbing, 
rather than by faulting and tectonics as appears to be the case at the four northern fields (Ferrini et al., 2008). The transition from basalt in the north to basaltic andesite in the south, with much greater influence from subduction, is abrupt along the ELSC, occurring over only $\sim 15 \mathrm{~km}$ south of TowCam as the spreading axis shoals from 2500 to 2200 (Fig. 2)(Lau ISS Workshop Report, 2006; Michael and Seewald, 2007; Escrig et al., 2009). There is a gap of $142 \mathrm{~km}$ between ABE and the three southern fields within which several hydrothermal plumes were found (Baker et al., 2006), but which we did not have time to investigate.

Submarine hydrothermal fluids represent the integrated effects of reaction between seawater and the rocks of the oceanic lithosphere, phase separation, and the release of volatile species during magmatic degassing. The direction and magnitude of chemical exchange associated with these processes is influenced by numerous variables that include temperature, pressure, water/rock ratio, rock composition and texture, and subsurface hydrology. Accordingly, substantial differences in the physical and chemical conditions along the ELSC may significantly influence the composition of high-temperature vent waters from north to south in Lau Basin. Results of this study show systematic variations in the physical and chemical properties of vent waters from Kilo Moana in the north to Tui Malila in the south, while farther to the south, the Mariner and Vai Lili vent fields are distinct in both temperature and fluid composition.

Assessing the response of vent water chemistry to changes in crustal structure and composition is complex due to large differences in the chemical behavior of a given species during high-temperature water-rock reaction. Species typically referred to as "mobile" or "soluble", for example, readily partition into the aqueous phase during water-rock reaction and are only slightly incorporated into secondary alteration minerals (Mottl et al., 1978; Seyfried et al., 1984; Von Damm, 1995). Their abundance in high-temperature hydrothermal fluids is controlled mainly by substrate composition and water/rock ratio rather than by temperature and pressure. In contrast, the abundances of species regulated by reversible chemical equilibrium, commonly referred to as solubility controlled species, respond systematically to changes in temperature, pressure, and the composition of the chemical system. The aqueous concentration of a solubility controlled species will not directly reflect its abundance in the substrate due to its incorporation into secondary alteration minerals. Although each type of species can be used as a geochemical indicator to elucidate water-rock reactions in the subsurface, the response to 
changing physical and chemical conditions from north to south along the ELSC may be very different.

\subsection{Temperature}

Measured temperature represents an excellent example of how hydrothermal activity is influenced by changing conditions along the ridge axis. The decrease in hot spring temperatures southward from Kilo Moana to Tui Malila (Fig. 4) is consistent with circulation deeper into the crust at the northern sites, as suggested by Martinez et al. (2006) based on a lower magma supply there; a lower temperature of intrusion for more silicic magma at the southern sites; and/or a higher water/rock ratio in the more porous silicic magma that characterizes the VFR, as suggested by the oxygen isotope composition of the fluids (see below). Temperature could also be influenced by buoyancy, which increases dramatically with increasing temperature and decreasing pressure in the near-critical region of seawater $\left(407^{\circ} \mathrm{C}, 298\right.$ bar; Bischoff and Rosenbauer, 1985). The decrease in maximum measured temperature from TowCam to ABE is consistent with shoaling of the ridge axis from $\sim 2700 \mathrm{~m}$ to $\sim 2100 \mathrm{~m}$ between these two vent fields. Further shoaling from ABE to Tui Malila is accompanied by a further decrease in average temperature, although the temperature of the hottest vent at Tui Malila is similar to that at ABE, suggesting seafloor depth is not the only factor influencing vent fluid temperature. The high maximum temperature at Mariner $\left(363^{\circ} \mathrm{C}\right)$ in spite of its relatively shallow water depth $(1920 \mathrm{~m})$ likely reflects input of high-enthalpy magmatic volatiles (see below) and/or differences in subsurface hydrology associated with the absence of faulting.

\subsection{Role of substrate composition}

In general, the chemistry of the vent fields we sampled does not readily fall into the three groups defined above on the basis of geology and substrate. Vent fields within the same group, including Kilo Moana and Towcam on one hand and the three VFR fields on the other, do not strongly resemble one another, and transitions from one group to another tend to be gradual rather than abrupt. In particular, the hot springs in the four northernmost fields, which span all three groups, show a more gradual and continuous variation than the abrupt changes in substrate 
lithology and depth would suggest. This observation is perhaps not surprising considering that a high degree of compositional heterogeneity is observed in crustal rocks at all locations (Fig. 3), and this heterogeneity would be averaged by the circulating hydrothermal fluids. It clearly implies, however, that substrate is not the dominant factor determining vent composition. The hot springs at Tui Malila represent in most ways a continuation of trends shown by the three fields much farther to the north, even though they lie shallower than $1900 \mathrm{~m}$ depth on more felsic rocks on the VFR, south of the 142-km gap in our sampling. This generalization holds for temperature, $\mathrm{H}_{2} \mathrm{~S}, \mathrm{Si},{ }^{87} \mathrm{Sr} /{ }^{86} \mathrm{Sr}$, alkalinity, $\mathrm{Li}, \mathrm{Na} / \mathrm{Cl}, \mathrm{K}, \mathrm{Rb}, \mathrm{Cs}, \mathrm{B}, \delta^{11} \mathrm{~B}, \mathrm{~F}, \mathrm{I}$, and $\delta^{7} \mathrm{Li}$. The largest discontinuity in hot spring chemistry lies between Tui Malila and the Mariner field, which also lies on the VFR and is only $25 \mathrm{~km}$ farther south (although Tui Malila apparently has only basaltic andesite, whereas dacites and rhyolites lie close to the vents at Mariner). This discontinuity can be seen in temperature, $\mathrm{H}_{2} \mathrm{~S}$, pH, alkalinity, $\mathrm{Fe}, \mathrm{Mn}, \mathrm{F}, \mathrm{CO}_{2}, \mathrm{Na} / \mathrm{Cl}, \mathrm{K}, \mathrm{Rb}$, and Cs.

Although ridge segments along the ELSC are not characterized by distinct fluid composition, there are some chemical trends that correlate directly with variations in substrate composition from north to south. As felsic volcanism becomes more abundant southward due to the influence of the subducted slab, the trace element composition of the rocks also changes. The $\mathrm{Ba} / \mathrm{La}$ ratio in crustal rocks is an excellent indicator of the slab component because these elements are not fractionated during partial melting or fractional crystallization, but retain the relative abundance of their source. High $\mathrm{Ba} / \mathrm{La}$ ratios are indicative of an elevated slab contribution (Pearce et al., 2005). Although they display a wide range in composition at any location, rock samples collected as part of the R2K Lau ISS initiative show that gradients in $\mathrm{Ba} / \mathrm{La}$ and other parameters do not vary smoothly with distance from the arc or along axis, but show instead a steep gradient between TowCam and ABE (Fig. 3). The rapid increase in Ba/La and $\mathrm{Ba}$ concentration between TowCam and $\mathrm{ABE}$ and the more gradual increase farther south would be accompanied by increased abundances of other incompatible elements such as $\mathrm{K}, \mathrm{Rb}$, Cs, B, and Cl (Bezos et al., 2009; Escrig et al., 2009).

A striking feature of the chemical composition of ELSC vent fluids is the strong correlation of mobile trace element abundances and substrate composition. Boron increases steadily from north to south as far as the Mariner field (Fig. 11), and K, Rb, and Cs increase southward as far as Tui Malila (Fig. 8), consistent with the higher abundance of these species in more slab-influenced 
felsic rocks. The close relationship between mobile trace elements in fluids and rocks is emphasized by the compositional changes between TowCam and ABE. Rock Ba/La ratios that remain constant between Kilo Moana and TowCam show a rapid increase over the $50 \mathrm{~km}$ that separates TowCam from ABE (Fig. 3). This trend is duplicated by the abundances of dissolved $\mathrm{K}, \mathrm{Rb}, \mathrm{Cs}$, and B, which are similar at Kilo Moana and TowCam and increase substantially at $\mathrm{ABE}$, suggesting that the source regions for these high-temperature fluids do not extend for large distances along axis.

Fluid-mobile elements such as $\mathrm{Rb}, \mathrm{Cs}$, and $\mathrm{B}$ can be used to estimate water/rock ratios in hydrothermal systems if their concentrations in the rock are known (Mottl and Holland, 1978; Von Damm et al., 1985). Because the spread in rock composition is so large at each vent field, these calculations are highly approximate. Using data for $\mathrm{Rb}$ and $\mathrm{Cs}$ in glasses from the Lau Basin from PetDB (Lehnert et al., 2000) and from Bezos et al. (2009), we estimate water/rock mass ratios for the six vent fields in 2005 to be in the range 1.6 to 3.7 (Table 4). These are maximum values because the calculation assumes $100 \%$ extraction of $\mathrm{Rb}$ and $\mathrm{Cs}$ from the rock. They show no obvious trend along axis. The oxygen isotopic composition of ELSC vent fluids (Fig. 12: $\delta^{18} \mathrm{O}=0.1$ to $1.1 \%$, heavier than seawater because of input of oxygen from the rock)

indicates similarly low water/rock ratios (Shanks, 1995). Lower $\delta^{18} \mathrm{O}$ values at the three southern vent fields that are more similar to the seawater value suggest higher water/rock ratios in their high-temperature reaction zones than at the three northern fields. Low water/rock ratios indicate that water-rock interaction in subsurface reaction zones is occurring under rock-dominated conditions that likely buffer the abundance of solubility controlled aqueous species in response to fluid-mineral equilibria (Bowers et al., 1985; Berndt et al., 1989; Seyfried et al., 1991).

Aqueous $\mathrm{Li}$ is another mobile species that is typically used to estimate water/rock ratios. Unlike $\mathrm{Rb}$ and $\mathrm{Cs}$, however, aqueous $\mathrm{Li}$ follows $\mathrm{Na} / \mathrm{Cl}$ in decreasing in vent waters from north to south (Fig. 7), despite being enriched in more felsic rocks. This trend suggests that Li is not behaving as a mobile trace element, but instead is being regulated in solution by a secondary alteration phase.

\subsubsection{Chloride variability}

Enrichments and depletions of $\mathrm{Cl}$ relative to seawater in mid-ocean ridge vent fluids are typically attributed to phase separation (Butterfield et al., 1994, Von Damm et al., 1997; Seewald 
et al. 2003; Seyfried et al., 2003). Maximum measured temperatures at the Mariner vent field $\left(363^{\circ} \mathrm{C}\right)$ are very close to the two-phase boundary for seawater at the seafloor depth of $1920 \mathrm{~m}$ $\left(365^{\circ} \mathrm{C}\right.$; Bischoff and Rosenbauer, 1985), consistent with on-going phase separation at this location. Fluids from the four northern vent fields, however, have measured temperatures significantly below the two-phase boundary, indicating that if phase separation has affected these fluids, extensive subsurface cooling has occurred prior to venting at the seafloor. Most fluids at mid-ocean ridge hydrothermal systems are characterized by non-seawater $\mathrm{Cl}$ concentrations and vent at temperatures below the two-phase boundary, suggesting that phase separation followed by cooling is a pervasive phenomenon (German and Von Damm, 2004; Von Damm, 1995).

In addition to phase separation, vent fluid $\mathrm{Cl}$ concentrations may be enriched by leaching of rock-derived $\mathrm{Cl}$. Leaching of $\mathrm{Cl}$ from rocks has not been considered as a source of $\mathrm{Cl}$ enrichment in mid-ocean ridge hydrothermal systems because mid-ocean ridge basalts contain very low concentrations of $\mathrm{Cl}$. Back-arc basin basalts, however, are substantially enriched in $\mathrm{Cl}$ relative to mid-ocean ridge basalts, and thus warrant consideration as a source of $\mathrm{Cl}$ to hightemperature vent fluids in the Lau Basin. $\mathrm{Cl}$ abundances in crustal rocks along the ELSC show a high degree of variability at a given latitude and, except for an apparent decrease from Kilo Moana to TowCam, show an increase from north to south (Fig. 13). In general, ELSC vent fluids are characterized by large enrichments relative to seawater by as much as $22 \%$, although a few fluids at TowCam, ABE, and Mariner show minor depletions ( $\leq 2 \%)$ (Fig. 7). Variations in ventfluid chlorinity along axis are remarkably similar to variations in rock $\mathrm{Cl}$ content: both show a decrease from Kilo Moana to TowCam and an increase farther south (Figs. 7 and 14), suggesting that leaching of $\mathrm{Cl}$ from rock during high-temperature alteration may contribute to the elevated $\mathrm{Cl}$ in ELSC vent fluids. Such an interpretation is consistent with the predominance of brines and the scarcity of conjugate $\mathrm{Cl}$-depleted vapors. Rock hydration during hydrothermal alteration may also result in small degrees of vent fluid $\mathrm{Cl}$ enrichment. TowCam and ABE fluids with small $\mathrm{Cl}$ depletions may be indicative of minor Cl-fixation in amphiboles as is observed in hydrothermally altered rocks from oceanic spreading centers (Ito et al. 1983).

Observed $\mathrm{Br} / \mathrm{Cl}$ ratios in the ELSC show little variation and are close to seawater values. At first glance, this might be interpreted as evidence to suggest phase separation is responsible for $\mathrm{Cl}$ variability since $\mathrm{Cl}$ and $\mathrm{Br}$ do not fractionate during phase separation at near-critical conditions (Berndt and Seyfried, 1990; Foustoukos and Seyfried, 2007). However, Br/Cl molar 
ratios in mid-ocean ridge basalts (1.1) and arc volcanics (1.5 to 1.8; Villemant et al., 2008) are not substantially different from that in seawater (1.54). If it is assumed that the $\mathrm{Br} / \mathrm{Cl}$ ratio of back-arc crust lies somewhere between that of mid-ocean ridge basalts and arc volcanics, mass balance constraints do not allow leaching of halides from back-arc volcanics to change significantly the $\mathrm{Br} / \mathrm{Cl}$ ratio of vent fluids that have relatively small $\mathrm{Cl}$ enrichments $(\leq 22 \%)$. In this case, therefore, constant $\mathrm{Br} / \mathrm{Cl}$ ratios in vent fluids of varying chlorinity do not require phase separation.

Data for the abundance of $\mathrm{Cl}$ in rocks along the ELSC (Fig. 13) allow assessment of water/rock mass ratios in a similar manner to the calculations above based on $\mathrm{Rb}$ and $\mathrm{Cs}$, if we attribute the entire vent-fluid $\mathrm{Cl}$ enrichment over seawater values to rock leaching. Water/rock ratios so calculated vary from 0.1 to 0.9 (Table 4), with no apparent trend from north to south. These values are somewhat lower than those calculated from Rb and Cs, suggesting either that $\mathrm{Rb}$ and $\mathrm{Cs}$ are incompletely leached or that the entire $\mathrm{Cl}$ increase cannot be attributed to rock leaching, and some must result from phase separation and/or rock hydration. None of these processes are mutually exclusive and all may play a role in regulating vent fluid $\mathrm{Cl}$ abundances at Lau Basin. Overall, the range of water/rock mass ratios is comparable to values calculated for mid-ocean ridge hydrothermal systems based on $\mathrm{Li}, \mathrm{K}$, and $\mathrm{Rb}$, (0.3 to 1.9; Von Damm et al., $1985)$ and B isotopic methods (0.28-0.66; Spivack and Edmond, 1987), and all indicate waterrock reaction under rock-dominated conditions.

Concentrations of $\mathrm{Cl}$ that approach $0.15 \mathrm{wt} \%$ in nearby rocks at Mariner, and the presence of vent fluids at the two-phase boundary for seawater, provide an excellent example of vent-fluid $\mathrm{Cl}$ abundances that may be influenced by both rock leaching and active phase separation. If it is assumed that Mariner fluids have the same or higher $\mathrm{Cl}$ content as at Tui Malila prior to phase separation, then all fluids at Mariner may represent a vapor phase formed from a brine, despite absolute $\mathrm{Cl}$ concentrations in Mariner fluids that are in excess of the seawater value.

\subsubsection{Contribution from subducted sediment}

The strongest evidence for increased input from subducted sediment southward as the arc is approached is iodine (Fig. 11) (Campbell and Edmond, 1989; You et al., 1994). This element increases steadily from Kilo Moana in the north to Mariner in the south, along with F, $\delta^{7} \mathrm{Li}$, and 
B. Boron concentrations on the ELSC are exceptionally high among seafloor hot springs, and $\delta^{11} \mathrm{~B}$ is exceptionally low, especially to the south (Fig. 11). Both are exceeded only by fluids from sedimented ridges at the Okinawa Trough (You et al., 1994) and the Suiyo Seamount in the Izu-Bonin island arc (Ishibashi and Urabe, 1995). Although the scatter in $\delta^{11} \mathrm{~B}$ is large (Fig. 14), the two northern vents Kilo Moana and TowCam could arguably represent mixtures of seawater $B$ with B leached from basalt. The southern vents, including ABE and the three VFR fields, have an additional isotopic component, which is probably B desorbed from slab sediments, as suggested for the 1989 Vai Lili samples by You et al. (1994). Desorbed B has a $\delta^{11} \mathrm{~B}$ value of about $+15 \%$ (Spivack et al., 1987). Like I, the B data support a contribution from subducted sediment that increases to the south as the arc is approached.

The range in $\delta^{7} \mathrm{Li}$ in our samples is quite small, only +3 to $+7 \%$, but the trend is quite regular, increasing southward in parallel with I (Fig. 11) as the Li concentration decreases from 900 to $300 \mu \mathrm{mol} / \mathrm{kg}$, compared with only $27 \mu \mathrm{mol} / \mathrm{kg}$ in seawater at $+32 \%$ o $\delta^{7} \mathrm{Li}$. The narrow range in $\delta^{7} \mathrm{Li}$ is not diagnostic, as it overlaps the ranges for mid-ocean ridge basalt (MORB) of +3 to $+6 \%$, arc lavas of +1 to $+11 \%$, and sediments of -5 to $+8 \%$ (Tomascak, 2004) (Fig. 15). Nevertheless, its close tracking with I (Fig. 11) suggests that it too reflects a proportionately larger contribution from subducted sediment that increases to the south (although the concentration of Li decreases southward).

\subsection{Fluid-mineral equilibria}

Laboratory and theoretical studies have demonstrated that fluid-mineral equilibria under hydrothermal conditions are a sensitive function of temperature and pressure. It is not surprising, therefore, that aqueous concentrations of solubility controlled species in Lau vent waters vary systematically from north to south. Perhaps the best example of this is the observed $\mathrm{SiO}_{2(a q)}$ concentrations that decrease from a maximum value of $21.7 \mathrm{mmol} / \mathrm{kg}$ at Kilo Moana to 7.8 $\mathrm{mmol} / \mathrm{kg}$ at the low-temperature Vai Lili vents (Fig. 4). This trend is consistent with aqueous $\mathrm{SiO}_{2}$ abundance being controlled by quartz solubility, which increases with temperature and pressure below the critical point of seawater (Fournier, 1983; Von Damm et al., 1992; Foustoukos and Seyfried, 2007). 
Dissolved $\mathrm{Na}$ and $\mathrm{Ca}$ concentrations are likewise known to be buffered by fluid-rock reactions at elevated temperature and pressure. In particular, the stability of plagioclase solid solutions plays a critical role in regulating $\mathrm{Na}$ and $\mathrm{Ca}$ in solution (Seyfried et al, 1987; Berndt et al., 1989; Seyfried et al., 1991; Berndt and Seyfried, 1993) according to the reaction:

$$
\underset{\text { anorthite }}{\mathrm{CaAl}_{2} \mathrm{Si}_{2} \mathrm{O}_{8}+2 \mathrm{Na}^{+}+4 \mathrm{SiO}_{2(a q)}=\underset{\text { albite }}{2 \mathrm{NaAlSi}_{3} \mathrm{O}_{8}}+\mathrm{Ca}^{2+}}
$$

where anorthite and albite represent the calcic and sodic components of plagioclase solid solution, respectively. The extent of Na-fixation that occurs in response to albitization decreases with increasing temperature due to a decrease in the equilibrium constant for reaction 1 (Seyfried et al., 1988). Because $\mathrm{Na}$ is the major cation in seafloor hydrothermal fluids, charge balance, mass action, and compositional constraints require that its concentration be closely linked to chloride in fluids with salinity near that of seawater. Accordingly, when evaluating along-axis variations in aqueous $\mathrm{Na}$ abundance it is useful to normalize end-member $\mathrm{Na}$ concentrations to chloride. The $\mathrm{Na} / \mathrm{Cl}$ ratio decreases from north to south along the ELSC to values significantly below that of seawater (Fig. 7). While phase separation and rock hydration have a minor effect on aqueous $\mathrm{Na} / \mathrm{Cl}$ ratios (Bernd and Seyfried, 1997), the influence of $\mathrm{Cl}$ leaching is unknown due to a lack of information on the mode of $\mathrm{Cl}$ occurrence in rocks, the mechanisms associated with release of $\mathrm{Cl}$ to solution, and the cation that is ultimately needed to balance charge. Although the decrease in the $\mathrm{Na} / \mathrm{Cl}$ ratio may be attributed to addition of rock-derived $\mathrm{Cl}$ if $\mathrm{Na}$ is not the cation that balances charge, it is also consistent with an increase in the extent of albitization from north to south, a trend that, except for the volatile influenced Mariner and Vai Lili vent fluids, is generally consistent with decreasing temperatures (Fig. 4). The $\mathrm{Na} / \mathrm{Cl}$ ratio at Kilo Moana appears slightly anomalous, however, as it is slightly higher than at TowCam, the similar temperatures and aqueous $\mathrm{SiO}_{2}$ concentrations notwithstanding. Decreased albitization may suggest higher temperatures in deep-seated reaction zones at Kilo Moana that are masked by subsequent cooling of fluids during upflow to the seafloor.

Additional evidence for enhanced albitization to the south is provided by along-axis variations in $\mathrm{Li}$ abundance that are virtually identical to those observed for $\mathrm{Na} / \mathrm{Cl}$ ratios (Fig.7). Although Li is typically viewed as a mobile element during hydrothermal fluid-rock interaction 
(Seyfried et al., 1984), it is also incorporated into extensively albitized mid-ocean ridge basalts (Shaw et al., 1977). Moreover, laboratory experiments have demonstrated uptake of Li during albitization of calcic plagioclase at greenschist-facies temperatures (Seewald, 1987). Accordingly, both $\mathrm{Na}$ and Li provide evidence for plagioclase buffering of major and trace elements in ELSC vent fluids.

Aqueous $\mathrm{Ca}$ and $\mathrm{Sr}$ represent additional species influenced by plagioclase equilibria under hydrothermal conditions (Berndt et al., 1988, 1989). Ca concentrations are consistent with the extent of albitization as indicated by $\mathrm{Na} / \mathrm{Cl}$ ratios. Kilo Moana fluids, e.g., have the lowest $\mathrm{Ca}$ concentrations, consistent with high $\mathrm{Na} / \mathrm{Cl}$ ratios, while increases in $\mathrm{Ca}$ in the southern vent fluids (Fig. 9) are consistent with enhanced albitization. It has been well documented that waterrock reactions that regulate $\mathrm{Ca}$ concentration also regulate the abundance of $\mathrm{Sr}$ (Berndt et al., 1989; Ravizza et al., 2001), and this is clearly the case in ELSC vent fluids as evidenced by the strong covariation of $\mathrm{Ca}$ and $\mathrm{Sr}$ (Fig. 9).

Because Sr isotopes (Fig. 9) do not fractionate during dissolution and precipitation reactions, they can be used to identify sources and sinks for $\mathrm{Sr}$ and $\mathrm{Ca}$ in subsurface environments. The Sr isotopic composition of ELSC vent waters shows a strong linear correlation when plotted against 1/Sr (Fig. 16). This trend is not consistent with simple mixing between $\mathrm{Sr}$ from seawater $\left({ }^{87} \mathrm{Sr} /{ }^{86} \mathrm{Sr}=0.70910\right)$ and $\mathrm{Sr}$ from crustal rocks along the VFR $\left({ }^{87} \mathrm{Sr} /{ }^{86} \mathrm{Sr}=0.7032\right.$; Vallier et al., 1991; Escrig et al., 2009), which would produce significantly higher ${ }^{87} \mathrm{Sr} /{ }^{86} \mathrm{Sr}$ values for a given $\mathrm{Sr}$ concentration than is observed. Berndt et al. (1988) have shown that the relationship between ${ }^{87} \mathrm{Sr} /{ }^{86} \mathrm{Sr}$ and $\mathrm{Sr}$ abundance observed in mid-ocean ridge vent waters can be accounted for by a two-stage evolution involving 1) early precipitation of anhydrite during recharge that results in removal of $\mathrm{Sr}$ and $\mathrm{Ca}$ from solution, followed by 2) dissolution of primary plagioclase that releases $\mathrm{Sr}$ and $\mathrm{Ca}$ to solution in high-temperature reaction zones. Early- stage precipitation removes seawater $\mathrm{Sr}$ from solution, while subsequent dissolution of plagioclase adds rock $\mathrm{Sr}$, decreasing the ${ }^{87} \mathrm{Sr} /{ }^{86} \mathrm{Sr}$ ratio and increasing the $\mathrm{Sr}$ concentration in solution.

The precipitation/dissolution model of Berndt et al. (1988) can be applied to the ELSC vent fluids to estimate the amount of Sr removed during recharge and the extent of plagioclase dissolution. Figure 17 shows that the correlation of ${ }^{87} \mathrm{Sr} /{ }^{86} \mathrm{Sr}$ ratio with $\mathrm{Sr}$ concentration is consistent with mixing between a low-Sr fluid containing approximately $23 \mu \mathrm{m} / \mathrm{kg}$ produced by 
precipitation of anhydrite, with varying amounts of rock $\mathrm{Sr}$ characterized by a ${ }^{87} \mathrm{Sr} /{ }^{86} \mathrm{Sr}$ ratio of 0.7032, similar to that measured in andesitic rocks from the VFR (Vallier et al., 1991). The narrow range of $\mathrm{Sr}$ concentrations indicated for the fluid prior to mixing with rock Sr suggests that the amount of anhydrite precipitated is relatively uniform along the entire length of the ELSC. This result is somewhat surprising considering the large variations in depth and subsurface hydrology from north to south.

Estimated water/rock ratios according to the precipitation/dissolution model vary from 10 to 20, and are higher than values estimated based on the abundance of mobile species. Water/rock ratio estimates, however, are species-specific and provide different types of information. Mobile elements such as $\mathrm{K}, \mathrm{Rb}, \mathrm{Cs}, \mathrm{B}$, and $\mathrm{Cl}$ tend to be rapidly and quantitatively released from interstitial glass and unstable phases, and so provide an indicator of the total amount of rock physically encountered by a fluid. In contrast, Sr resides mainly in the more stable phases plagioclase and clinopyroxene. The higher water/rock ratios calculated from $\mathrm{Sr}$ isotopes thus will reflect alteration of only these Sr-bearing phases. Moreover, the model utilized above is likely an oversimplification of what is actually occurring in the subsurface, since $\mathrm{Sr}$ is incorporated into secondary alteration phases such as hydrothermal plagioclase, epidote, and amphiboles. As noted by Berndt et al. (1989), non-unique, path-dependent models that account for incorporation of $\mathrm{Sr}$ into alteration phases other than anhydrite produce lower estimated water/rock ratios.

Despite these uncertainties, the relative distribution of water/rock ratio should reflect the extent of plagioclase recrystallization during albitization. Thus, water/rock ratios that decrease from Kilo Moana, to similar values at TowCam and ABE, to even lower values at Tui Malila (Fig. 16), are entirely consistent with other aspects of fluid composition that suggest increasing albitization from north to south. Neither Mariner nor Vai Lili as sampled in 1989 fit with this trend, probably because the extremely high $\mathrm{H}^{+}$activity in those two fields influences the stability of Sr-bearing phases.

The major element composition of submarine hydrothermal fluids plays a critical role in regulating their in situ $\mathrm{pH}$ and their ability to transport metals, the aqueous activity of which is controlled by the solubility of sulfide minerals. Several studies have demonstrated that in basalthosted systems acidity is generated in high-temperature reaction zones by Ca-fixation in clinozoisite (the Ca-component of epidote solid solution) or in other Ca-bearing minerals such as 
amphiboles (Seyfried et al, 1987; Berndt et al., 1989; Seyfried et al., 1991). High Ca activity in solution is maintained by the stability of calcic plagioclase, which buffers $\mathrm{Na} / \mathrm{Ca}$ ratios at temperatures near the critical point of seawater. The effectiveness of Ca-fixation as a mechanism for generating acidity and mobilizing metals decreases dramatically with decreasing temperature and anorthite activity (Seyfried and Janecky, 1985; Berndt et al., 1989; Seewald and Seyfried, 1990; Seyfried et al., 1991). Increasing $\mathrm{pH}$ (as measured at $25^{\circ} \mathrm{C}$ ) and decreasing concentrations of dissolved metals from Kilo Moana to Tui Malila (Fig. 6) indicate that the ability of vent fluids to transport metals to the seafloor is decreasing from north to south. This trend likely reflects both a southward decrease in temperature and a change in substrate composition as the anorthite component of plagioclase decreases in more felsic rocks to the south. The influence of temperature and $\mathrm{pH}$ is also evident in the aqueous concentrations of dissolved $\mathrm{H}_{2} \mathrm{~S}$ that systematically decrease from north to south (Fig. 6).

The possibility that temperatures in deep-seated reaction zones may be significantly higher than values measured at the seafloor at Kilo Moana, as suggested by $\mathrm{Na} / \mathrm{Cl}$ ratios and $\mathrm{Ca}$ concentrations, is supported by the lower $\mathrm{pH}\left(25^{\circ} \mathrm{C}\right)$ and higher $\mathrm{H}_{2} \mathrm{~S}, \mathrm{Fe}$, and $\mathrm{Mn}$ concentrations than at TowCam. Indeed, measured Fe concentrations at Kilo Moana are almost an order of magnitude higher than at TowCam, consistent with a $\mathrm{pH}\left(25^{\circ} \mathrm{C}\right)$ that is substantially lower. That Fe concentrations are significantly higher at Kilo Moana than is typically observed in submarine hot springs at temperatures $\leq 333^{\circ} \mathrm{C}$ (Von Damm, 1995; German and Von Damm, 2004) suggests that cooling and subsequent ascent of hydrothermal fluid to the seafloor at Kilo Moana is sufficiently rapid to preclude re-equilibration as the solutions cool.

\subsection{Intra-field variability}

Many of the basin-wide trends observed in the composition of vent waters along the ELSC are also apparent within the $665 \mathrm{~m}$ length of spreading axis sampled at the ABE vent field. For example, end-member concentrations of mobile elements K, Rb, Cs (Fig. 8), Cl (Fig. 7), and I (Fig. 11) increase from north to south, a trend that can be attributed to a local continuation of the steep gradient in substrate composition observed on a larger scale between TowCam and ABE. Alternatively, increasing abundances of mobile trace elements may reflect decreasing 
water/rock ratios from north to south within the ABE field, as suggested by oxygen isotopes (Fig. 12). Presently, the data do not allow us to distinguish between these two possibilities.

Systematic intra-field compositional variation at $\mathrm{ABE}$ is not limited to mobile elements, but applies as well to the concentrations of solubility controlled species. Aqueous $\mathrm{SiO}_{2}, \mathrm{Na} / \mathrm{Cl}$, $\mathrm{Fe}, \mathrm{Mn}$, and $\mathrm{H}_{2} \mathrm{~S}$ all decrease from north to south with temperature (Figs. 4, 6, and 7), while $\mathrm{pH}$ $\left(25^{\circ} \mathrm{C}\right), \mathrm{Ca}$, and $\mathrm{Sr}$ increase (Figs. 6 and 10). As is the case for the basin-wide trends, these variations are consistent with decreasing temperature within the $\mathrm{ABE}$ vent field, from a maximum of $309^{\circ} \mathrm{C}$ at the northern vents to $295^{\circ} \mathrm{C}$ at the southern vents. This decrease results in greater albitization, lower aqueous $\mathrm{SiO}_{2}$ due to reduced quartz solubility, higher $\mathrm{pH}$, and reduced metal mobility.

Variations in the Sr isotopic composition and Sr concentration of the vent waters also indicate decreased water/rock ratio to the south within the ABE field. In particular, the southernmost waters contain the highest $\mathrm{Sr}$ concentration and lowest ${ }^{87} \mathrm{Sr} /{ }^{86} \mathrm{Sr}$ ratio (Fig. 9), consistent with reaction at lower water/rock ratio (Fig. 16). It is not possible to determine whether this reflects an increase in the amount of rock that has reacted with fluids or enhanced albitization due to lower temperatures. The observation that mobile trace elements increase to the south in conjunction with lowered measured vent temperatures, however, suggests that both processes are important.

\subsection{Role of magmatic gases}

The chemistry of vent fluids at the four northern vent fields along the ELSC is very similar to fluids from numerous basalt-hosted mid-ocean ridge hydrothermal systems sampled at similar temperatures (Von Damm 1995; German and Von Damm, 2004). In the 2005 Lau data set, however, an abrupt change in chemistry occurs between Tui Malila and Mariner, two fields on the VFR that are only $25 \mathrm{~km}$ apart, resulting in fluid compositions at Mariner and Vai Lili that are not observed at mid-ocean ridges. Vent waters at Mariner are significantly hotter, more acid and metal-rich, less saline, and richer in dissolved gases and other volatiles, including $\mathrm{H}_{2} \mathrm{~S}, \mathrm{CO}_{2}$, and F (Figs. 6 and 11), than those at Tui Malila and vents farther north. These characteristics are similar to those that prevailed at Vai Lili in 1989 (Fouquet et al., 1993). Although differences in fluid composition are expected at Mariner due to higher temperatures of water-rock reaction and 
active phase separation at and below the seafloor, the extreme levels of acidity and associated metal mobility are not observed in basalt-hosted mid-ocean ridge hydrothermal systems at similar or higher temperatures that are also experiencing active phase separation (Butterfield et al., 1994; Von Damm et al., 1997; Seyfried et al., 2003). Because the substrate at Mariner is similar to that at Tui Malila (except for nearby dacites at Mariner), the substantial difference in fluid composition suggests a fundamental shift in geochemical processes regulating fluid composition.

The dramatically lower $\mathrm{pH}$ and higher $\mathrm{CO}_{2}$ and fluoride in Mariner vent fluids is almost certainly due to input of magmatic volatiles from an actively degassing magma chamber. It is possible that for the more felsic magmas of this region, $\mathrm{SO}_{2}$ represents a stable sulfur species that is degassed (Wallace, 2001). Mixing of any magmatically derived $\mathrm{SO}_{2}$ with convecting hydrothermal fluids would cause the $\mathrm{SO}_{2}$ to disproportionate on cooling into sulfuric acid and either one or both of elemental sulfur and $\mathrm{H}_{2} \mathrm{~S}$, depending on temperature and the redox state of the fluid (Gamo et al., 1997). Thus, addition of magmatic gases rich in sulfuric acid along with $\mathrm{HCl}$ and $\mathrm{HF}$ will greatly increase the acidity of convecting seawater-derived hydrothermal fluids, enabling them to carry exceptionally high concentrations of chalcophile metals such as $\mathrm{Fe}, \mathrm{Cu}$, and $\mathrm{Zn}$. Elevated sulfate concentrations would not be expected in fluids affected by $\mathrm{SO}_{2}$ addition because the high concentration of $\mathrm{Ca}$ and the strong retrograde solubility of anhydrite (Bischoff and Seyfried, 1978; Holland and Malinin, 1979) would cause anhydrite to precipitate, leaving low $\mathrm{pH}$ as the only evidence of subsurface $\mathrm{SO}_{2}$ contributions. Evidence for subsurface precipitation of anhydrite by this mechanism has been reported from drillcore samples recovered from beneath the PACMANUS hydrothermal system in the eastern Manus Basin (Roberts et al., 2003).

High concentrations of fluoride at Mariner, well above that in seawater, may be diagnostic of a magmatic input, as ridge-crest hydrothermal fluids are generally depleted in fluoride relative to seawater (Edmond et al., 1979; Von Damm et al., 1985), as are the four northern vent fields of the ELSC reported here (Fig. 10). Laboratory experiments suggest that fluoride substitutes for $\mathrm{OH}^{-}$in hydrous phases during water-rock reactions at 150 to $250^{\circ} \mathrm{C}$, but that it is highly mobile at temperatures $>250^{\circ} \mathrm{C}$ (Seyfried and Ding, 1995). The sharp increase in fluoride at Mariner does not appear to correlate with substrate composition, which shows a continuous and gradual southward increase in F beginning in the region of Kilo Moana (Fig. 13). 
Mass balance calculations based on the abundances shown in Fig. 13 indicate that very little of the fluoride present in crustal rocks of the ELSC is mobilized into solution during water-rock reaction. The elevated concentrations appear to reflect direct injection of magmatic volatiles under temperature and $\mathrm{pH}$ conditions that limit the formation of fluoride-bearing phases.

The absence of evidence for magmatic degassing into the hydrothermal system at Tui Malila is intriguing, as seismic data indicate that both Mariner and Tui Malila are underlain by magma chambers (Jacobs et al., 2007), though the horizontal extent of the reflector beneath Mariner is exceptionally large (Collier and Sinha, 1992). This observation suggests that if the magma chamber at Tui Malila is degassing, then differences in subsurface hydrology, perhaps due to the presence or absence of extensive faulting, is preventing these volatiles from interacting with seawater-derived hydrothermal fluids. Alternatively, low abundances of magmatic volatiles in Tui Malila vent fluids may reflect a lack of magmatic degassing due to differences in the volatile content of magmas at these two locations. Jacobs et al. (2007) have suggested that an increase in the thickness of crustal layer $2 \mathrm{~A}$ and a deepening of the magma chamber between Tui Malila and Mariner is due to increased abundance of magmatic volatiles at Mariner. These geophysical observations are consistent with the composition of vent fluids at Tui Malila and Mariner.

\section{SUMMARY AND CONCLUSIONS}

The ELSC displays large and systematic variation in spreading rate, magma source and lava chemistry, axial depth and morphology, melt lens characteristics, crustal structure, and proximity to the volcanic arc over its 397-km length. These variations are strongly reflected in the chemistry of the fluids we sampled for this study from six hydrothermal vent fields that span $247 \mathrm{~km}$ of the ELSC. For some elements the composition of the hot springs depends directly on a geologic parameter, as in the case of the fluid-mobile elements $\mathrm{K}, \mathrm{Rb}$, and $\mathrm{Cs}$, which depend on crustal composition. The concentrations of these elements increase southward as far as the Tui Malila vent field as the arc is approached and the crust becomes more felsic. Vent field chloride variations likewise seem to be related to concentrations of $\mathrm{Cl}$ in the substrate, in addition to phase separation. In similar fashion B, I, and $\delta^{7} \mathrm{Li}$ increase southward all the way to the Mariner vent field, and $\delta^{11} \mathrm{~B}$ decreases, indicating an increasing southward influence of subducted 
sediment. A second direct dependency applies to those chemical species introduced by magmatic degassing, such as $\mathrm{F}$ and $\mathrm{CO}_{2}$ at the Mariner vent field, and the effect of magmatic gases on $\mathrm{pH}$. For other chemical species, however, their chemistry depends indirectly on geologic and geophysical parameters, via the effect of these parameters on changes in temperature, pressure, and water/rock ratio, related to the hydrogeology of the hydrothermal fields. Solubility controlled species that are largely determined by temperature include $\mathrm{pH}$ (which rises as temperature decreases southward to Tui Malila), $\mathrm{Si}, \mathrm{H}_{2} \mathrm{~S}, \mathrm{Li}, \mathrm{Na}, \mathrm{Ca}$, and $\mathrm{Sr}$. Fe and $\mathrm{Mn}$ respond to both temperature and $\mathrm{pH}$. Oxygen isotopes respond mainly to changes in water/rock ratio, which is apparently higher in the felsic rocks of the Valu Fa Ridge. Sr isotopes respond to both temperature and water/rock ratio.

The large variations in geologic and geophysical parameters produced by back-arc spreading along the ELSC exceed those along mid-ocean ridge spreading axes and differ significantly in their interrelationships, especially between spreading rate and magma supply. These variations provide important new insights into the specific processes that control the chemistry of submarine hydrothermal springs.

Acknowledgments. We thank the captain, crew, and technicians of the R/V Melville, and the crew of the DSV Jason, for enabling us to discover the Tui Malila vent field and to collect such an excellent suite of samples at all six vent fields and to map them so thoroughly. The authors thank the scientists and crew members of R/V Kilo Moana (KM0417; Charles Langmuir, Chief Scientist) and R/V Southern Surveyor (TELVE; Richard Arculus, Chief Scientist) for their tremendous efforts in mounting field programs to obtain rock samples. We thank the U.S. National Science Foundation and its RIDGE 2000 Program for funding this study via grants OCE0241826 (to MJM), OCE0242902 (to PJM), OCE0241796 (to JSS, MKT), and OCE0242088 (to CGW), as well as the Deep Ocean Exploration Institute at WHOI (to GP, ER). We thank Drs. Jun-Ichiro Ishibashi and Kentaro Nakamura and two anonymous reviewers for their helpful comments. We dedicate this work to the memory of Drs. Karen Von Damm and Lui-Heung Chan, and especially their mentor Dr. John Edmond, who did so much to further our understanding of hydrothermal vent chemistry over the past three decades. 


\section{REFERENCES}

Baker E. T., Resing J. A., Walker S. L., Martinez F., Taylor B. and Nakamura K. (2006) Abundant hydrothermal venting along melt-rich and melt-free segments in the Lau back-arc basin. Geophys. Res. Lett. 33, L07308, doi:10.1029/2005GL025283.

Berndt M. E. and Seyfried W. E. Jr. (1993) Calcium and sodium exchange during hydrothermal alteration of calcic plagioclase at $400^{\circ} \mathrm{C}$ and 400 bars. Geochim. Cosmochim. Acta 57, 44454451.

Berndt M. E. and Seyfried W. E. Jr. (1990) Boron, bromide, and other trace elements as clues to the fate of chlorine in mid-ocean ridge vent fluids. Geochim. Cosmochim. Acta 54, 2235-2245.

Berndt M. E., Seyfried W. E. Jr. and Janecky D. R. (1989) Plagioclase and epidote buffering of cation ratios in mid-ocean ridge hydrothermal fluids: experimental results in the near supercritical region. Geochim. Cosmochim. Acta 53, 2283-2300.

Berndt M. E., Seyfried W. E. Jr. and Beck J. W. (1988) Hydrothermal alteration processes at midocean ridges: experimental and theoretical constraints from $\mathrm{Ca}$ and $\mathrm{Sr}$ exchange reactions and $\mathrm{Sr}$ isotopic ratios. J. Geophys. Res. 93, 4573-4583.

Bézos A., Escrig S., Langmuir C. H., Michael P. J. and Asimow P. D. (2009) Origins of chemical diversity of back-arc basin basalts: a segment scale study of the Eastern Lau Spreading Center. $J$. Geophys. Res. 114, B06212, doi:10.1029/2008JB005924, 30 June 2009.

Bischoff J. L. and Rosenbauer R. B. (1985) An empirical equation of state for hydrothermal seawater (3.2 percent NaCl). Amer. J. Sci. 285, 725-763.

Bischoff J. L. and Seyfried W. E. Jr. (1978) Hydrothermal chemistry of seawater from $25^{\circ}$ to $350^{\circ}$ C. Amer. J. Sci. 278, 838-860.

Bowers T. S., Von Damm K. L. and Edmond J. M. (1985) Chemical evolution of mid-ocean ridge hot springs. Geochim. Cosmochim. Acta 49, 2239-2252.

Butterfield D. A., McDuff R. E., Mottl M. J., Lilley M. D., Lupton J. E. and Massoth G. J. (1994) Gradients in the composition of hydrothermal fluids from the Endeavour segment vent field: phase separation and brine loss. J. Geophys. Res. 99, 9561-9583.

Campbell A. C. and Edmond J. M. (1989) Halide systematics of submarine hydrothermal vents. Nature 342, 168-170.

Collier J.S. and Sinha M.C. (1992) Seismic mapping of a magma chamber beneath the Valu Fa Ridge, Lau Basin. J. Geophys. Res. 97, 14,031-14,053. 
Crawford W. C., Hildebrand J. A., Dorman L. M., Webb S. C. and Wiens D. A. (2003) Tonga Ridge and Lau Basin crustal structure from seismic refraction data. J. Geophys. Res. 108, doi:10.1029/2001JB001435.

Detrick R. S., Sinton J. M., Ito G., Canales J. P., Behn M., Blacic T., Cushman B., Dixon J. E., Graham D. W. and Mahoney J. (2002) Correlated geophysical, geochemical and volcanological manifestations of plume-ridge interaction along the Galapagos Spreading Center. Geochem., Geophys., Geosyst. 3 (10), 8501, doi:10.1029/ 2002GC000350, 2002.

Edmond J. M., Massoth G. and Lilley M. D. (1992) Submersible deployed samplers for axial vent waters. RIDGE Events 3 (1), 23-24.

Edmond J. M., Measures C., McDuff R. E., Chan L. H., Collier R., Grant B., Gordon L. I. and Corliss J. B. (1979) Ridge crest hydrothermal activity and the balances of the major and minor elements in the ocean: the Galapagos data. Earth Plan. Sci. Lett. 46, 1-18.

Escrig S., Bézos A., Goldstein S. L., Langmuir C. H. and Michael P. J. (2009) Mantle source variations beneath the Eastern Lau Spreading Center and the nature of subduction components in the Lau basin-Tonga arc system. Geochem., Geophys., Geosyst. 10, Q04014, doi:10.1029/2008GC002281.

Ferrini V. L., Tivey M. K., Carbotte S. M., Martinez F. and Roman C. (2008) Variable morphologic expression of volcanic, tectonic, and hydrothermal processes at six hydrothermal vent fields in the Lau back-arc basin. Geochem. Geophys. Geosystems 9 (7), doi:10.1029/2008GC002047.

Fouquet Y., von Stackelberg U., Charlou J. L., Erzinger J., Herzig P. M., Muhe R. and Wiedicke M. (1993) Metallogenesis in back-arc environments: the Lau Basin example. Econ. Geol. 88, 2154-2181.

Fournier R. 0. ( 1983) A method of calculating quartz solubilities in aqueous sodium chloride solutions. Geochim. Cosmochim. Acta 47, 579-586.

Foustoukos D. I. and Seyfried W. E. Jr. (2007) Trace element partitioning between vapor, brine and halite under extreme phase separation conditions. Geochim. Cosmochim. Acta 71, 20562071.

Franklin J. M., Lydon J. W. and Sangster D. F. (1981) Volcanic-associated massive sulfide deposits. Econ. Geol. 75, 485-627.

Gamo T., Okamura K., Charlou J.-L., Urabe T., Auzende J.-M., Ishibashi J., Shitashima K., Chiba H. and the Shipboard Scientific Party of the ManusFlux Cruise (1997) Geology 25, 139142.

German C. R. and Von Damm K. L. (2004) Hydrothermal processes. In The Treatise on Geochemistry, edited by K. K. Turekian and H. D. Holland, chap. 6.07, pp. 181-222, Elsevier, 
New York.

German C. R., Yoerger D. R., Jakuba M., Shank T. M., Langmuir C. H. and Nakamura K. (2008) Hydrothermal exploration with the Autonomous Benthic Explorer. Deep Sea Res. Pt. I. 55 (2), 203-219. 10.1016/j.dsr.2007.11.004.

Gieskes J. M., Gamo T. and Brumsack H. (1991) Chemical methods for interstitial water analysis aboard JOIDES Resolution. Ocean Drilling Program, Texas A\&M University, Tech. Note 15, College Station TX, 59 pp.

Hannington M. D., de Ronde C. E. J. and Petersen S. (2005). Sea-floor tectonics and submarine hydrothermal systems, p. 111-141 in 100th Anniversary Volume of Economic Geology. J. Hedenquist et al., eds., Society of Economic Geologists, Littleton, Colorado.

Herzig P., Hannington M. D., Fouquet Y., von Stackelberg U. and Petersen S. (1993) Gold-rich polymetallic sulfides from the Lau back arc and implications for the geochemistry of gold in seafloor hydrothermal systems of the Southwest Pacific, Econ. Geol. 88, 2182-2209.

Holland H. D. and Malinin S. D. (1979) The solubility and occurrence of non-ore minerals. In Geochemistry of Hydrothermal Ore Deposits (ed. H. L. Barnes), pp. 461-508. WileyInterscience.

Ishibashi J.-I. and Urabe T. (1995) Hydrothermal activity related to arc-backarc magmatism in the western Pacific. In B. Taylor (ed.), Backarc Basins;Tectonics and Magmatism, 451-495, Plenum Press, New York.

Ishibashi, J.-I., Lupton J. E., Yamaguchi T., Querellou J., Nonoura T. and Takai K. (2006) Expedition reveals changes in Lau Basin hydrothermal system, Eos Trans. AGU 87(2), 13, doi:10.1029/2006EO020001.

Ito E., Harris D. M. and Anderson A.T. Jr. (1983) alteration of oceanic crust and geologic cycling of chlorine and water. Geochim. Cosmochim Acta 47, 1613-1624.

Jacobs A. M., Harding A. J. and Kent G. M. (2007) Axial crustal structure of the Lau back-arc basin from velocity modeling of multichannel seismic data. Earth. Planet. Sci. Lett. 259, 239$255,2007$.

Lau Integrated Studies Site Focus Workshop (2006) RIDGE 2000 Workshop Report, 19 pp.

Lehnert K., Su Y., Langmuir C., Sarbas B. and Nohl U. (2000) A global geochemical database structure for rocks. Geochem. Geophys. Geosyst. 1, doi:10.1029/1999GC00026.

Martinez F. and Taylor B. (2002) Mantle wedge control on back-arc crustal accretion. Nature 416, 417-420. 
Martinez F., Taylor B., Baker E. T., Resing J. A. and Walker S. L. (2006) Opposing trends in crustal thickness and spreading rate along the back-arc Eastern Lau Spreading Center: implications for controls on ridge morphology, faulting, and hydrothermal activity, Earth Planet. Sci. Lett. 245, 655-672.

Michael P. and Seewald J. (2007) Focus On: Studies at the Lau Basin. Ridge Events 2, 11-21.

Mottl M. J. and Holland H. D. (1978) Chemical exchange during hydrothermal alteration of basalt by seawater. I. Experimental results for major and minor components of seawater. Geochim. Cosmochim. Acta 42, 1103-1115.

Pearce J. A., Stern R. J., Bloomer S. H. and Fryer P. (2005) Geochemical mapping of the Mariana arc-basin system: Implications for the nature and distribution of subduction Components. Geochem. Geophys. Geosys. 6, no. 7, Q07006, doi:10.1029/2004GC000895.

Proskurowsi G., Seewald J. S., Reeves E., McCollom T. M., Lupton J., Sylva S. and Tivey M. K. (2007) Volatile chemistry at Lau Basin hydrothermal sites: basin-wide trends of slab carbonate influence and suggestions of abiotic methane oxidation at the Mariner vent site, Eos Trans. AGU, 88 (52), abstract V34B-04.

Ravizza G., Blusztajn, J., Von Damm, K. L., Bray A. M., Bach W. and Hart S. R. (2001) Sr isotope variations in vent fluids from $9^{\circ} 46^{\prime}-9^{\circ} 54$ 'N East Pacific Rise: Evidence of a non-zeroMg fluid component. Geochim. Cosmochim Acta 65, 729-739.

Roberts S., Bach W., Binns R. A., Vanko D. A., Yeats C. J., Teagle D. A. H., Blacklock K., Blusztajn J. S., Boyce A. J. and Cooper M. J. (2003) Contrasting evolution of hydrothermal fluids in the PACMANUS system, Manus Basin: The $\mathrm{Sr}$ and $\mathrm{S}$ isotope evidence. Geology 31 (9), 805-808.

Sawkins F. J. (1990) Metal Deposits in Relation to Plate Tectonics. Springer-Verlag.

Seewald J. S. (1987) Na and Ca metasomatism during hydrothermal basalt alteration: an experimental and theoretical study. Unpublished M.Sc. Thesis, University of Minnesota. 75 p.

Seewald J. S. and Seyfried W. E. Jr. (1990) The effect of temperature on metal mobility in subseafloor hydrothermal systems: constraints from basalt alteration experiments. Earth Planet. Sci. Lett. 101, 388-403.

Seewald J. S., Cruse A. and Saccocia P. (2003) Aqueous volatiles in hydrothermal fluids from the Main Endeavour Field, northern Juan de Fuca Ridge: temporal variability following earthquake activity. Earth Planet. Sci. Lett. 216, 575-590.

Seewald J. S., Doherty K. W., Hammar T. R. and Liberatore S. P. (2002) A new gas-tight isobaric sampler for hydrothermal fluids. Deep-Sea Res. Pt. 1, 49, 189-196. 
Seyfried W. E. Jr. and Ding K. (1995) The hydrothermal chemistry of fluoride in seawater. Geochim. Cosmochim. Acta 59, 1063-1071.

Seyfried W. E. Jr. and Janecky D. R. (1985) Heavy metal and sulfur transport during subcritical and supercritical hydrothermal alteration of basalt: influence of fluid pressure and basalt composition and crystallinity. Geochim. Cosmochim. Acta 49, 2545-2560.

Seyfried W. E. Jr., Seewald J. S., Berndt M. E., Ding K. and Foustoukos D. (2003) Chemistry of hydrothermal vent fluids from the Main Endeavour Field, Northern Juan de Fuca Eidge: Geochemical controls in the aftermath of the June 1999 seismic events. J. Geophys. Res. 108, 2429-2452.

Seyfried W. E. Jr., Ding K. and Berndt M. E. (1991) Phase equilibria constraints on the chemistry of hot spring fluids at mid-ocean ridges. Geochim. Cosmochim. Acta 55, 3559-3580.

Seyfried W. E., Jr., Berndt M.E. and Seewald J. S. (1988). Hydrothermal alteration processes at mid-ocean ridges: constraints from diabase alteration experiments, hot-spring fluids and composition of the oceanic crust. Can. J. Earth Sci. 26, 787-804.

Seyfried W. E. Jr., Janecky D. R. and Mottl M. J. (1984) Alteration of the oceanic crust: implications for geochemical cycles of lithium and boron. Geochim. Cosmochim. Acta 48, 557569.

Shanks W. C. III, Böhlke J.K. and Seal R.R. II (1995) Stable isotopes in mid-ocean ridge hydrothermal systems: interactions between fluids, minerals and organisms. In S. E. Humphris, R. A. Zierenberg, L. S. Mullineaux and R. E. Thomson (eds.), Seafloor Hydrothermal Systems: Physical, Chemical, Biological, and Geological Interactions. Geophys. Mono. 91, Amer. Geophys. Union, 194-221.

Shaw D. M., Vatin-Perignon N., and Muysson J. R. (1977) Lithium in spilites. Geochim. Cosmochim. Acta 41, 1601-1607.

Spivack A. J. and Edmond J. M. (1987) Boron isotope exchange between seawater and the oceanic crust. Geochim. Cosmochim. Acta 51, 1033-1043.

Spivack A. J., Palmer M. R. and Edmond J. M. (1987) The sedimentary cycle of the boron isotopes. Geochim. Cosmochim. Acta 51, 1939-1949.

Takai K., Nunoura T., Ishibashi J.-I., Lupton J., Suzuki R., Hamasaki H., Ueno Y., Kawagucci S., Gamo T., Suzuki Y., Hirayama H. and Horikoshi K. (2008) Variability in the microbial communities and hydrothermal fluid chemistry at the newly discovered Mariner hydrothermal field, southern Lau Basin. J. Geophys. Res. 113, G02031, doi:10.1029/2007JG000636.

Tivey M. K., Craddock P., Seewald J., Ferrini V., Kim S., Mottl M., Sterling A., Reysenbach A.L. and Wheat C.G. (2005) Characterization of six vent fields within the Lau Basin, Eos Trans. 
Amer. Geophys. Union 86 (52), Fall Meet. Suppl., Abstract: T31A-0477.

Tomascak P. B. (2004) Developments in the understanding and application of lithium isotopes in the earth and planetary sciences, Rev. Mineral. Geochem. 55, 153-195.

Turner I. M., Peirce C. and Sinha M. C. (1999) Seismic imaging of the axial region of the Valu Fa Ridge, Lau Basin - the accretionary processes of an intermediate back-arc spreading axis. Geophys. J. Int. 138, 495-519.

T. L. Vallier, Jenner G. A., Frey F. A., Gill J. B., Davis A. S., Volpe A. M., Hawkins J. W., Morris J. D., Cawood P. A., Morton J. L., Scholl D. W., Rautenschlein M., White W. M., Williams R. W., Stevenson A. J. and White L. D. (1991) Subalkaline andesite from Valu Fa Ridge, a back-arc spreading center in southern Lau Basin: petrogenesis, comparative chemistry, and tectonic implications. Earth Planet. Sci. Lett. 91, 227-256.

Villemant B., Mouatt J. and Michel A. (2008) Andesitic magma degassing investigated through $\mathrm{H} 2 \mathrm{O}$ vapour-melt partitioning of halogens at Soufrière Hills Volcano, Montserrat (Lesser Antilles). Earth Planet. Sci. Lett. 269, 212-229.

Von Damm K. L. (1995) Controls on the chemistry and temporal variability of seafloor hydrothermal fluids. In S. E. Humphris, R. A. Zierenberg, L. S. Mullineaux and R. E. Thomson (eds.), Seafloor Hydrothermal Systems: Physical, Chemical, Biological, and Geological Interactions. Geophys. Mono. 91, Amer. Geophys. Union, 222-247.

Von Damm K. L., Buttermore L. G., Oosting S. E., Bray A. M. Fornari D. J., Lilley M. D. and Shanks W. C. III (1997) Direct observation of the evolution of a seafloor 'black smoker' from vapor to brine. Earth. Planet. Sci. Lett. 149, 101-111.

Von Damm K. L., Bischoff J. L. and Rosenbauer R. J. (1992) Quartz solubility in hydrothermal seawater: an experimental study and equation describing quartz solubility for up to $0.5 \mathrm{M} \mathrm{NaCl}$ solutions. Amer. J. Sci. 291, 977-1007.

Von Damm K. L., Edmond J. M., Grant B., Measures C. I., Walden B. and Weiss R. F. (1985) Chemistry of submarine hydrothermal solutions at $21^{\circ} \mathrm{N}$, East Pacific Rise. Geochim.

Cosmochim. Acta 49, 2197-2220.

Wallace P. J. (2001) Volcanic $\mathrm{SO}_{2}$ emissions and the abundance and distribution of exsolved gas in magma bodies. J. Volc. Geotherm. Res. 108, 85-106.

You C.-F., Butterfield D. A., Spivack A. J., Gieskes J. M., Gamo T. and Campbell A. J. (1994) Boron and halide systematics in submarine hydrothermal systems: effects of phase separation and sedimentary contributions, Earth Planet. Sci. Lett. 123, 227-238.

Zellmer K. E., and Taylor B. (2001) A three-plate kinematic model for Lau Basin opening. Geochem. Geophys. Geosys. 2, 2000GC000106, 2001. 


\section{Figure Captions}

Figure 1. Location of known active hydrothermal vent fields along the Eastern Lau Spreading Center (ELSC). Inset: Map of the Lau Basin showing spreading centers (heavy lines) and arc volcanoes (triangles). Areas above $2000 \mathrm{~m}$ are shaded gray. CLSC and ILSC $=$ Central and Intermediate Lau Spreading Centers, respectively.

Figure 2. Along-axis depth profile of the Eastern Lau Spreading Center showing the location of known active vent fields and the extent of a seismically imaged melt lens.

Figure 3. Along-axis depth profile of the Eastern Lau Spreading Center showing the location of known active vent fields, compared with ratios of the highly incompatible elements $\mathrm{Ba} / \mathrm{La}$ in volcanic rocks sampled from the same latitude (Bezos et al., 2009; Escrig et al., 2009). Note the abrupt transition from mafic to felsic rocks at $20.6^{\circ} \mathrm{S}$, just north of the ABE vent field.

Figure 4. Top: Measured temperature of vents from the six vent fields, based on 65 measurements from 40 vents sampled in this study in 2005 (circles and squares), plus temperature at the Vai Lili vent field in 1989 (Fouquet et al., 1993) and maximum temperature at the Mariner field in 2004 (Takai et al., 2008)(stars). Intrafield spatial variation is shown within each vertical panel, as the 2005 temperature data are plotted against distance along the long-axis of each vent field (see section 4.0). The width of each panel represents $1000 \mathrm{~m}$ (see scale bar). The 1989 and 2004 data (solid stars) are arbitrarily positioned within each panel to facilitate temperature comparison only. Besides the stars for Vai Lili in 1989 and Mariner in 2004, symbols denote $\mathrm{Mg}$ concentration, in $\mathrm{mmol} / \mathrm{kg}$, measured in each sample from 2005: black 
squares $0.7-9$, gray squares $12-35$, gray circles $45-49.5$. The open squares and circles denote the corresponding measured temperatures extrapolated to zero $\mathrm{Mg}$. When the eight high-Mg fluids are corrected to zero Mg to account for mixing, all but three (A6, TM9, MA4) of these cooler vents (excepting Vai Lili) have temperatures similar to the high-temperature vents from the same vent field, demonstrating that they were cooled mainly by mixing with bottom seawater, introduced just prior to sampling, either naturally within the edifice or artificially at the orifice. Bottom: End-member Si, based on 77 samples collected from 40 vents in 2005, plus earlier samples from the Vai Lili vent field in 1989 and the Mariner field in 2004. Bottom seawater contained $0.13 \mathrm{mmol} / \mathrm{kg} \mathrm{Si}$. Symbols are as above except that open circles have been replaced by plusses.

Figure 5. Mg vs. sulfate in all 81 vent water samples collected for this study, from 43 vents at six vent fields. The dotted line connects seawater with the origin. Error bars for analytical uncertainty are smaller than the symbols.

Figure 6. $\mathrm{pH}$ measured at $25^{\circ} \mathrm{C}$ and zero- $\mathrm{Mg}$ end-member $\mathrm{Fe}, \mathrm{Mn}$, and $\mathrm{H}_{2} \mathrm{~S}$ in 40 vents from six vent fields, based on 77 vent water samples collected in 2005, plus earlier samples from the Vai Lili vent field in 1989 and the Mariner field in 2004 (stars). Other symbols denote Mg concentration, in mmol/kg, measured in each sample from 2005: black squares 0.7-9, open squares 12-38, plusses 45-49.5. Bottom seawater at the six vent fields ranged in $\mathrm{pH}$ from 7.50 to 7.64 . 
Figure 7. End-member chlorinity, $\mathrm{Na}, \mathrm{Na} /$ chlorinity, and Li in 40 vents from six vent fields, based on 77 vent water samples collected in 2005, plus earlier samples from the Vai Lili vent field in 1989 and the Mariner field in 2004 (stars). Other symbols denote Mg concentration and are as in Figure 6. Li in bottom seawater is $26.6 \square \mathrm{mol} / \mathrm{kg}$.

Figure 8. End-member K, Rb, and $\mathrm{Cs}$ in 40 vents from six vent fields, based on 77 vent water samples collected in 2005, plus earlier samples from the Vai Lili vent field in 1989 and the Mariner field in 2004 (stars). Other symbols denote Mg concentration and are as in Figure 6.

Figure 9. End-member Ca, Sr, and Sr isotopic ratio at six vent fields sampled in 2005, plus earlier samples from the Vai Lili vent field in 1989 and the Mariner field in 2004 (stars). Other symbols denote $\mathrm{Mg}$ concentration and are as in Figure 6. $\mathrm{Ca}$ and $\mathrm{Sr}$ are based on 77 vent water samples collected in 2005 from 40 vents. The Sr isotopic ratio for the waters is for 18 representative samples from 18 different vents that have $1.5-4.2 \mathrm{mmol} / \mathrm{kg} \mathrm{Mg}$ (except at Vai Lili, which has 13.8 and $18.8 \mathrm{mmol} / \mathrm{kg}$ ). The end-member Sr isotopic composition was calculated by extrapolating the measured values against 1/Sr to the zero-Mg end-member Sr concentration. Bottom seawater has a $\mathrm{Sr}$ isotopic ratio of 0.7091 . The $\mathrm{Sr}$ isotopic ratio for the rocks (solid circles) is shown for each vent field for which there are data, using an average weighted by distance from the vents for all samples within $6 \mathrm{~km}$. The error bars display the total range.

Figure 10. End-member $\mathrm{CO}_{2}$ and $\mathrm{F}$ in 40 vents from six vent fields sampled in 2005, plus earlier samples from the Mariner field in 2004 (stars). Other symbols denote Mg concentration and are 
as in Figure 6. $\mathrm{CO}_{2}$ is based on 50 samples collected in 2005 from 33 vents, and $\mathrm{F}$ on 77 samples from 40 vents. Bottom seawater contains $2.3 \mathrm{mmol} / \mathrm{kg}$ dissolved inorganic carbon (DIC).

Figure 11. End-member I, $\square{ }^{7} \mathrm{Li}$, B, and $\square^{11} \mathrm{~B}$ at six vent fields sampled in 2005, plus earlier samples from the Vai Lili vent field in 1989 and the Mariner field in 2004 (stars). Other symbols denote $\mathrm{Mg}$ concentration and are as in Figure 6. B concentration is based on 77 vent water samples collected in 2005 from 40 vents. Other species are based on 18 representative samples from 18 vents that have $1.5-4.2 \mathrm{mmol} / \mathrm{kg} \mathrm{Mg}$ (except at Vai Lili, which has 13.8 and 18.8 $\mathrm{mmol} / \mathrm{kg}$ ). The end-member $\mathrm{Li}$ and $\mathrm{B}$ isotopic compositions were calculated by extrapolating the measured values against 1/Li and 1/B to the zero-Mg end-member $\mathrm{Li}$ and $\mathrm{B}$ concentrations. The $\delta^{7} \mathrm{Li}$ ratio in seawater lies within the range $31.5 \pm 2.2$; analyses by TIMS suggests a value of about 32.5 (Tomascak, 2004).

Figure 12. End-member $\mathrm{O}$ and $\mathrm{H}$ isotopic composition at six vent fields, based on 32 vent water samples collected in 2005 from 31 different vents. These samples have $0.7-9 \mathrm{mmol} / \mathrm{kg} \mathrm{Mg}$ (except for Vai Lili, with 13.8 and $18.8 \mathrm{mmol} / \mathrm{kg}$ ). Symbols denote $\mathrm{Mg}$ concentration and are as in Figure 6. The dashed horizontal lines are for ambient bottom seawater, as measured. The solid horizontal line in the $\delta^{18} \mathrm{O}$ plot emphasizes the almost complete lack of overlap between the three northern fields and the three southern fields.

Figure 13. Concentrations of $\mathrm{Cl}$ and $\mathrm{F}$ in volcanic rocks vs. latitude along the Eastern Lau Spreading Center compared with end-member $\mathrm{Cl}$ and $\mathrm{F}$ in the vent waters. Note that the rocks and the water are plotted on different concentration scales. Rock data are from P.J. Michael; 
analytical uncertainty $( \pm 2 \sigma)$ is \pm 0.0025 (smaller than symbols) for $\mathrm{Cl}$ and \pm 0.008 for $\mathrm{F}$, as shown by representative error bar.

Figure 14. End-member $\square^{11} \mathrm{~B}$ vs. the ratio of the $\mathrm{B}$ concentration in seawater to that in the hydrothermal end-member solution for the six vent fields, based on 18 water samples collected from 18 vents in 2005, plus three samples from Vai Lili collected in 1989 (Fouquet et al., 1993). Lines connecting seawater with the values for $\mathrm{B}$ in mid-ocean ridge basalt (MORB) and of $\mathrm{B}$ desorbed from sediment (Spivack et al., 1987) indicate that most of the data can be modeled as mixtures of B from these three sources.

Figure 15. End-member $\square^{7} \mathrm{Li}$ the ratio of the Li concentration in seawater to that in the hydrothermal end-member solution for the six vent fields sampled in 2005, based on 18 water samples from 18 vents. These samples have $0.7-9 \mathrm{mmol} / \mathrm{kg} \mathrm{Mg}$ (except for Vai Lili, with 13.8 and $18.8 \mathrm{mmol} / \mathrm{kg}$ ). The lower figure expands the horizontal scale of the upper figure. Lines connecting seawater with a range of values for $\mathrm{Li}$ in mid-ocean ridge basalt (MORB) (Tomascak, 2004) indicate that most of the data can be modeled as mixtures of B from these two sources.

Figure 16. End-member ${ }^{87} \mathrm{Sr} /{ }^{86} \mathrm{Sr}$ vs. the ratio of the Sr concentration in seawater to that in the hydrothermal end-member solution for the six vent fields sampled in 2005, based on 18 water samples from 18 vents in 2005, plus three samples from Vai Lili collected in 1989 (Fouquet et al., 1993). The data are plotted against the two-stage dissolution-precipitation model of Berndt et al. (1988) which shows one set of contours (thin solid lines) for Sr concentration in solution following early precipitation of anhydrite during recharge, and a second set (dashed lines) for the 
water/rock mass ratio prevalent during subsequent water/rock interaction in the high-temperature reaction zone with rock having a Sr isotopic ratio of 0.7032, as on the Valu Fa Ridge (Vallier et al, 1991; Escrig et al., 2009). Regression of the vent fluid data (thick solid line) indicates that the majority of ELSC fluids are consistent with approximately $75 \% \mathrm{Sr}$ removal and water/rock ratios from 10 to 20 (Table 4). 
Table 1. Vent fields sampled along the Eastern Lau Spreading Center (ELSC) in April-May 2005

\begin{tabular}{|c|c|c|c|c|c|c|c|c|c|c|c|c|c|c|}
\hline Vent field* & $\begin{array}{c}\text { Distance } \\
\text { along } \\
\text { axis } \\
(\mathrm{km})\end{array}$ & $\begin{array}{c}\text { Distance } \\
\text { to next } \\
\text { field S } \\
(\mathrm{km})\end{array}$ & $\begin{array}{c}\text { Opening } \\
\text { rate* }^{*} \\
(\mathrm{~cm} / \mathrm{yr})\end{array}$ & $\begin{array}{c}\text { Character } \\
\text { of axis }\end{array}$ & $\begin{array}{l}\text { Axial } \\
\text { area } \\
\left(\mathrm{km}^{2}\right)\end{array}$ & $\begin{array}{l}\text { Crustal } \\
\text { thick- } \\
\text { ness } \\
(\mathrm{km})\end{array}$ & $\begin{array}{c}\text { Layer 2A } \\
\text { thickness } \\
\quad(\mathrm{m})\end{array}$ & $\begin{array}{c}\text { Layer 2A } \\
\text { velocity } \\
(\mathrm{km} / \mathrm{s})\end{array}$ & $\begin{array}{l}\text { Volcanic } \mathrm{n} \\
\text { Flows }\end{array}$ & $\begin{array}{c}\text { norphology } \\
\text { Domes }\end{array}$ & $\begin{array}{l}\text { Faul } \\
\text { near- } \\
\text { axis, } \\
\text { large }\end{array}$ & $\begin{array}{l}\text { ting } \\
\text { in } \\
\text { vent } \\
\text { field }\end{array}$ & $\begin{array}{c}\text { Plume } \\
\text { incidence }\end{array}$ & $\begin{array}{l}\text { Distance } \\
\text { sampled } \\
\text { on } \\
\text { long axis } \\
\text { (m) }\end{array}$ \\
\hline N.end of ELSC & 0 & & 97 & & & $\sim 6$ & 500 & 2.9 & & & & & & \\
\hline Kilo Moana & 90 & 29 & 87 & no high & -3.8 & & 450 & 3.2 & pillow and & low relief & many & yes & 0.44 & 151 \\
\hline Towcam & 119 & 50 & 83 & no high & -0.8 & & 550 & 2.9 & lobate & low relief & many & yes & 0.44 & 196 \\
\hline $\mathrm{ABE}$ & 169 & 142 & 75 & rounded & -0.3 & & 750 & 2.8 & pillows, aa, & medium & some & yes & 0.38 & 644 \\
\hline Tui Malila & 310 & 21 & 55 & peaked & 1.6 & $7.5-9$ & 650 & 2.6 & finger flows & high relief & few & yes & 0.24 & 396 \\
\hline Mariner & 332 & 4 & 52 & peaked & 1.8 & 9 & 950 & 2.5 & aa and & high relief & none & none & 0.24 & 178 \\
\hline Vai Lili & 336 & -- & 51 & peaked & 2.4 & & 950 & 2.5 & finger flows & high relief & none & one & 0.24 & 166 \\
\hline S.end of ELSC & 397 & & 39 & & & & 1300 & 2.8 & & & & & & \\
\hline Ref. & 1 & 1 & 2,3 & 2 & 4 & 5,6 & 7 & 7 & 8 & 8 & 3,8 & & 2,9 & 1 \\
\hline
\end{tabular}

*Latitude and longitude of vent fields are given by Ferrini et al. (2008) and in the appendix.

${ }^{* *}$ calculated assuming a linear change with distance along the axis

${ }^{+}$distance from northernmostmost to southernmost vent sampled, as measured along the long axis of the vent field

References: 1) This paper, 2) Martinez et al. (2006), 3) Zellmer and Taylor (2001), 4) Martinez and Taylor (2002), 5) Turner et al. (1999), 6) Crawford et al. (2003), 7) Jacobs et al. (2007), 8) Ferrini et al. (2008), 9) Baker et al., (2006). 
Table 2. Endmember concentrations* of aqueous species in vent fluids from the Eastern Lau Spreading Center.

\begin{tabular}{|c|c|c|c|c|c|c|c|c|c|c|c|c|c|}
\hline Vent & $\underset{{ }^{\circ} \mathrm{Cax} . \mathrm{T}}{ }$ & $\underset{\mathrm{mm}}{\min . \mathrm{Mg}}$ & $\begin{array}{l}\mathrm{pH} \\
25^{\circ}\end{array}$ & $\begin{array}{c}\text { Alk } \\
\mathrm{meq} / \mathrm{kg}\end{array}$ & $\begin{array}{l}\mathrm{Na} \\
\mathrm{mm}\end{array}$ & $\begin{array}{c}\mathrm{K} \\
\mathrm{mm}\end{array}$ & $\begin{array}{l}\mathrm{Li} \\
\mu \mathrm{m}\end{array}$ & $\begin{array}{c}\delta^{7} \mathrm{Li} \\
\%\end{array}$ & $\begin{array}{l}\mathrm{Rb} \\
\mu \mathrm{m}\end{array}$ & $\begin{array}{l}\mathrm{Cs} \\
\mathrm{nm}\end{array}$ & $\begin{array}{l}\mathrm{Ca} \\
\mathrm{mm}\end{array}$ & $\begin{array}{l}\mathrm{Sr} \\
\mu \mathrm{m}\end{array}$ & ${ }^{87} \mathrm{Sr} /{ }^{86} \mathrm{Sr}$ \\
\hline \multicolumn{14}{|c|}{ Kilo Moana } \\
\hline KM1 & 333 & 1.6 & 3.6 & -0.37 & 486 & 16.9 & 875 & 2.90 & 9.8 & 106 & 34.9 & 118 & 0.70446 \\
\hline KM2 & 332 & 2.8 & 3.6 & -0.44 & 477 & 17.7 & 903 & & 9.2 & 99 & 35.0 & 122 & \\
\hline KM3 & 321 & 2.4 & 2.9 & -1.78 & 487 & 15.9 & 817 & 3.38 & 9.2 & 103 & 33.5 & 110 & 0.70445 \\
\hline KM4 & 300 & 2.2 & 3.2 & -1.02 & 481 & 17.0 & 882 & 3.67 & 9.9 & 112 & 36.0 & 123 & 0.70453 \\
\hline KM5 & 329 & 1.5 & 3.5 & -0.62 & 491 & 16.3 & 839 & & 9.7 & 104 & 34.0 & 111 & \\
\hline KM6 & 306 & 2.9 & 3.6 & -0.57 & 497 & 16.8 & 860 & 3.78 & 9.8 & 107 & 36.5 & 121 & 0.70442 \\
\hline KM8 & 333 & 1.8 & 4.0 & -0.37 & 490 & 17.3 & 897 & & 8.2 & 93 & 34.7 & 122 & \\
\hline \multicolumn{14}{|c|}{ TowCam } \\
\hline $\mathrm{TC} 1$ & 328 & 1.5 & 4.1 & -0.25 & 421 & 15.6 & 597 & 3.75 & 8.7 & 112 & 45.5 & 147 & 0.70439 \\
\hline TC3 & 320 & 0.7 & 4.0 & -0.29 & 423 & 14.7 & 576 & & 8.8 & 114 & 45.1 & 142 & \\
\hline TC4 & 316 & 2.3 & 4.1 & -0.08 & 422 & 14.8 & 576 & & 8.4 & 107 & 44.8 & 142 & \\
\hline TC5 & 302 & 3.3 & 3.7 & -0.49 & 442 & 16.1 & 620 & 4.19 & 9.1 & 116 & 43.4 & 146 & 0.70430 \\
\hline TC7 & 288 & 2.2 & 4.0 & -0.24 & 446 & 15.7 & 592 & 4.64 & 8.9 & 115 & 43.5 & 144 & 0.70434 \\
\hline TC8 & 308 & 1.5 & 4.1 & -0.32 & 425 & 14.8 & 578 & & 8.7 & 112 & 44.2 & 142 & \\
\hline \multicolumn{14}{|l|}{ ABE } \\
\hline A1 & 309 & 2.3 & 4.3 & -0.34 & 430 & 24.6 & 646 & 4.43 & 20 & 390 & 39.1 & 115 & 0.70422 \\
\hline A4 & 278 & 2.5 & 4.4 & -0.31 & 467 & 28.7 & 670 & 5.00 & 23 & 418 & 44.3 & 143 & 0.70415 \\
\hline A5 & 290 & 1.7 & 4.5 & -0.15 & 439 & 27.7 & 694 & 4.46 & 22 & 400 & 40.5 & 129 & 0.70422 \\
\hline A8 & 308 & 1.9 & 4.5 & -0.26 & 446 & 25.9 & 659 & & 23 & 411 & 39.4 & 120 & \\
\hline A9 & 295 & 2.8 & 4.6 & -0.20 & 476 & 27.4 & 649 & 4.45 & 23 & 415 & 44.2 & 136 & 0.70418 \\
\hline \multicolumn{14}{|c|}{ Tu'i Malila } \\
\hline TM1 & 279 & 5.5 & 4.5 & -0.35 & 509 & 44.4 & 614 & & 48 & 840 & 47.1 & 184 & \\
\hline TM2 & 312 & 1.9 & 4.4 & -0.12 & 512 & 43.6 & 612 & 5.76 & 49 & 866 & 47.5 & 180 & 0.70385 \\
\hline TM4 & $178^{\dagger}$ & 26.0 & 5.7 & -0.04 & 500 & 39.3 & 531 & & 38 & 671 & 46.7 & 168 & \\
\hline TM5 & 265 & 11.7 & 4.6 & -0.54 & 507 & 47.7 & 659 & & 50 & 863 & 47.0 & 178 & \\
\hline TM6 & 265 & 2.6 & 4.4 & 0.06 & 504 & 40.8 & 551 & 6.08 & 44 & 781 & 49.4 & 190 & 0.70382 \\
\hline TM7 & $198^{\dagger}$ & 12.1 & 5.0 & -0.03 & 505 & 38.8 & 530 & & 44 & 787 & 48.2 & 178 & \\
\hline TM8 & 229 & 2.7 & 4.4 & -0.09 & 500 & 43.4 & 582 & & 45 & 798 & 49.2 & 199 & \\
\hline TM10 & 274 & 2.2 & 4.2 & -0.11 & 508 & 42.6 & 590 & & 46 & 820 & 46.2 & 186 & \\
\hline \multicolumn{14}{|c|}{ Mariner } \\
\hline MA1 & 334 & 2.7 & 2.5 & -3.06 & 458 & 35.8 & 375 & 4.94 & 33 & 745 & 45.4 & 155 & 0.70413 \\
\hline MA2 & 311 & 8.9 & 2.6 & -4.49 & 449 & 35.1 & 362 & & 32 & 734 & 45.5 & 150 & \\
\hline MA3 & 363 & 1.9 & 2.7 & -2.25 & 439 & 36.9 & 385 & 5.86 & 32 & 735 & 43.8 & 162 & 0.70419 \\
\hline MA5 & 249 & 4.2 & 2.6 & -3.54 & 383 & 28.8 & 308 & 6.98 & 28 & 647 & 40.9 & 141 & 0.70424 \\
\hline MA6 & 240 & 3.7 & 2.7 & -3.06 & 385 & 29.3 & 312 & & 27 & 624 & 39.7 & 143 & \\
\hline \multicolumn{14}{|c|}{ Vai Lili } \\
\hline VLa & 40 & 44.8 & 6.5 & -0.23 & 518 & 37 & 377 & & 30 & 515 & 50.9 & 140 & \\
\hline VLb & 121 & 18.8 & 5.3 & -0.30 & 476 & 39 & 359 & 6.15 & 35 & 530 & 31.8 & 93 & 0.7054 \\
\hline VLc & 70 & 13.8 & 5.2 & -0.16 & 477 & 35 & 318 & 5.86 & 31 & 442 & 35.1 & 93 & 0.7056 \\
\hline \multicolumn{14}{|c|}{ Bottom Seawater } \\
\hline SW & 2 & 52.8 & 7.6 & 2.45 & 460 & 10.1 & 27 & 31.00 & 1.4 & 2.3 & 10.2 & 88 & 0.7091 \\
\hline
\end{tabular}


2 (continued)

\begin{tabular}{|c|c|c|c|c|c|c|c|c|c|c|c|c|c|}
\hline Vent & $\begin{array}{l}\mathrm{Chl} \\
\mathrm{mm}\end{array}$ & $\begin{array}{l}\mathrm{Br} \\
\mu \mathrm{m}\end{array}$ & $\begin{array}{c}\mathrm{F} \\
\mu \mathrm{m}\end{array}$ & $\begin{array}{c}\mathrm{I} \\
\mu \mathrm{m}\end{array}$ & $\begin{array}{c}\mathrm{SiO}_{2} \\
\mathrm{~mm}\end{array}$ & $\begin{array}{c}\mathrm{H}_{2} \mathrm{~S} \\
\mathrm{~mm}\end{array}$ & $\begin{array}{c}\mathrm{CO}_{2} \\
\mathrm{~mm}\end{array}$ & $\begin{array}{c}\mathrm{Mn} \\
\mu \mathrm{m}\end{array}$ & $\begin{array}{l}\mathrm{Fe} \\
\mu \mathrm{m}\end{array}$ & $\begin{array}{c}\mathrm{B} \\
\mu \mathrm{m}\end{array}$ & $\begin{array}{c}\delta^{11} \mathrm{~B} \\
\% 0\end{array}$ & $\begin{array}{c}\delta^{18} \mathrm{O}_{\text {vsmow }} \\
\% \text { o }\end{array}$ & $\begin{array}{c}\delta \mathrm{D}_{\mathrm{vsmow}} \\
\% \text { \% }\end{array}$ \\
\hline \multicolumn{14}{|c|}{ Kilo Moana } \\
\hline KM1 & 581 & 883 & 10.4 & 0.54 & 19.0 & 6.0 & 8.1 & 512 & 2485 & 535 & 25.7 & 0.82 & 2.2 \\
\hline KM2 & 575 & 925 & 9.5 & & 19.1 & 5.4 & 7.7 & 695 & 3202 & 518 & & 0.39 & -4.1 \\
\hline KM3 & 582 & 867 & 9.6 & 0.66 & 20.0 & 6.4 & 7.5 & 733 & 3836 & 508 & 27.2 & 0.45 & 0.6 \\
\hline KM4 & 574 & 893 & 10.4 & 0.66 & 19.0 & 5.4 & 8.2 & 526 & 2945 & 554 & 29.5 & 0.41 & -1.1 \\
\hline KM5 & 584 & 936 & 17.0 & & 21.7 & 6.3 & & 718 & 2916 & 525 & & 0.87 & -1.5 \\
\hline KM6 & 593 & 946 & 13.4 & 0.71 & 19.7 & 5.4 & & 676 & 3071 & 537 & 34.3 & 0.94 & -1.8 \\
\hline KM8 & 584 & 905 & 15.9 & & 20.6 & 5.5 & 8.5 & 553 & 2557 & 575 & & 1.08 & -0.9 \\
\hline \multicolumn{14}{|c|}{ TowCam } \\
\hline TC1 & 530 & 781 & 13.7 & 0.73 & 18.5 & 4.8 & 10.5 & 388 & 305 & 605 & 30.2 & 0.64 & -3.3 \\
\hline TC3 & 530 & 814 & 12.1 & & 18.7 & 4.9 & 10.6 & 398 & 267 & 551 & & 0.93 & -0.1 \\
\hline TC4 & 528 & 867 & 11.9 & & 18.9 & 4.9 & 10.7 & 407 & 282 & 514 & & & -2.5 \\
\hline TC5 & 549 & 897 & 8.4 & 0.85 & 18.6 & 4.5 & 11.5 & 332 & 332 & 584 & 26.5 & 0.92 & -2.1 \\
\hline TC7 & 551 & 884 & 7.7 & 0.88 & 20.1 & 3.7 & 11.1 & 389 & 368 & 531 & 17.7 & 0.96 & -0.7 \\
\hline TC8 & 530 & 837 & & & 19.3 & 5.2 & & 375 & 302 & 542 & & 0.96 & -0.9 \\
\hline \multicolumn{14}{|l|}{ ABE } \\
\hline A1 & 535 & 851 & 13.1 & 1.9 & 17.1 & 3.6 & 6.9 & 468 & 268 & 698 & 22.6 & 0.86 & -1.0 \\
\hline A4 & 585 & 938 & 17.2 & 2.0 & 15.8 & 2.8 & 5.1 & 273 & 225 & 825 & 25.8 & 0.70 & -0.6 \\
\hline A5 & 550 & 854 & 16.7 & 2.0 & 16.0 & 3.1 & 6.4 & 289 & 174 & 881 & 24.4 & 0.84 & 1.0 \\
\hline A8 & 553 & 869 & 16.9 & & 15.5 & 2.9 & 6.3 & 303 & 374 & 665 & & 0.89 & -1.2 \\
\hline A9 & 594 & 921 & 15.3 & 2.2 & 15.8 & 2.6 & 5.2 & 284 & 158 & 653 & 26.1 & 0.78 & -1.5 \\
\hline \multicolumn{14}{|c|}{ Tu'i Malila } \\
\hline TM1 & 651 & 1064 & 29.9 & & 14.0 & 2.3 & 12.6 & 433 & 219 & 1036 & & 0.28 & -0.6 \\
\hline TM2 & 653 & 1008 & 26.2 & 2.6 & 14.6 & 2.5 & 13.0 & 406 & 210 & 760 & 21.5 & 0.33 & -1.8 \\
\hline TM4 & 634 & 1041 & 33.0 & & 14.2 & 1.2 & 11.7 & 332 & 143 & 740 & & & \\
\hline TM5 & 654 & 1007 & 29.2 & & 16.4 & 2.3 & 13.8 & 441 & 199 & 1073 & & & \\
\hline TM6 & 646 & 974 & 20.1 & 3.0 & 15.3 & 2.4 & 12.4 & 399 & 218 & 915 & 26.4 & 0.20 & -1.5 \\
\hline TM7 & 642 & 968 & 19.8 & & 14.9 & 2.1 & 12.3 & 413 & 199 & 699 & & - & - \\
\hline TM8 & 644 & 1006 & & & 16.3 & 2.1 & & 380 & 153 & 836 & & 0.13 & -0.9 \\
\hline TM10 & 645 & 984 & 22.3 & & 16.7 & 2.0 & & 380 & 255 & 766 & & 0.25 & 0.1 \\
\hline \multicolumn{14}{|c|}{ Mariner } \\
\hline MA1 & 624 & 983 & 76.8 & 3.6 & 15.8 & 6.2 & 32.3 & 5938 & 11262 & 1010 & 24.9 & 0.34 & 1.9 \\
\hline MA2 & 618 & 917 & 112 & & 16.7 & 4.2 & 50.2 & 6276 & 11265 & 889 & & 0.40 & -1.3 \\
\hline MA3 & 605 & 972 & 71.4 & 3.5 & 15.1 & 9.3 & 39.8 & 5723 & 12991 & 1109 & 25.8 & 0.35 & 0.2 \\
\hline MA5 & 533 & 802 & 113 & 2.9 & 16.1 & 4.5 & 68.2 & 5441 & 10547 & 831 & 17.4 & 0.17 & -0.2 \\
\hline MA6 & 531 & 813 & 110 & & 16.3 & 6.4 & 71.4 & 4875 & 10684 & 879 & & 0.15 & -0.6 \\
\hline \multicolumn{14}{|c|}{ Vai Lili } \\
\hline VLa & 611 & 972 & 37.5 & & 13.6 & & 1.0 & 2644 & 237 & 753 & & & \\
\hline VLb & 590 & 900 & $<0$ & 2.0 & 8.9 & 0.013 & & 1363 & 127 & 807 & 18 & 0.40 & -6.4 \\
\hline VLc & 587 & 899 & $<0$ & 2.0 & 7.7 & 0.011 & 10.4 & 1403 & 148 & 612 & 27 & 0.34 & -3.9 \\
\hline \multicolumn{14}{|c|}{ Bottom Seawater } \\
\hline SW & 538 & 825 & 67.0 & 0.4 & 0.13 & 0.0 & 2.3 & 0 & 0 & 407 & 39.6 & -0.13 & -3.2 \\
\hline
\end{tabular}


Table 3. Measured concentrations* of aqueous species in high-Mg vent fluids from the Eastern Lau Spreading Center.

\begin{tabular}{|c|c|c|c|c|c|c|c|c|c|c|c|c|c|c|c|c|c|c|c|c|c|c|c|}
\hline Vent & Type $^{\S}$ & Sample \# & $\begin{array}{l}\mathrm{T} \\
{ }^{\circ} \mathrm{C}\end{array}$ & $\begin{array}{l}\mathrm{Mg} \\
\mathrm{mm}\end{array}$ & $\begin{array}{l}\mathrm{pH} \\
25^{\circ}\end{array}$ & $\begin{array}{c}\text { Alk } \\
\mathrm{meq} / \mathrm{kg}\end{array}$ & $\begin{array}{l}\mathrm{Na} \\
\mathrm{mm}\end{array}$ & $\begin{array}{c}\mathrm{K} \\
\mathrm{mm}\end{array}$ & $\begin{array}{l}\mathrm{Li} \\
\mu \mathrm{m}\end{array}$ & $\begin{array}{l}\mathrm{Rb} \\
\mu \mathrm{m}\end{array}$ & $\begin{array}{l}\text { Cs } \\
\mathrm{nm}\end{array}$ & $\begin{array}{l}\mathrm{Ca} \\
\mathrm{mm}\end{array}$ & $\begin{array}{l}\mathrm{Sr} \\
\mu \mathrm{m}\end{array}$ & $\begin{array}{c}\mathrm{SO}_{4} \\
\mathrm{~mm}\end{array}$ & $\begin{array}{l}\text { Chl } \\
\mathrm{mm}\end{array}$ & $\begin{array}{l}\mathrm{Br} \\
\mu \mathrm{m}\end{array}$ & $\begin{array}{c}\mathrm{F} \\
\mu \mathrm{m}\end{array}$ & $\begin{array}{c}\mathrm{SiO}_{2} \\
\mathrm{~mm}\end{array}$ & $\begin{array}{c}\mathrm{H}_{2} \mathrm{~S} \\
\mathrm{~mm}\end{array}$ & $\begin{array}{c}\mathrm{CO}_{2} \\
\mathrm{~mm}\end{array}$ & $\begin{array}{l}\mathrm{Mn} \\
\mu \mathrm{m}\end{array}$ & $\begin{array}{l}\mathrm{Fe} \\
\mu \mathrm{m}\end{array}$ & $\begin{array}{c}\text { B } \\
\mu \mathrm{m}\end{array}$ \\
\hline \multicolumn{24}{|c|}{ Kilo Moana } \\
\hline KM7 & basalt & J2-137-IGT7 & 11 & 50.7 & 7.1 & 2.09 & 460 & 10.3 & 33 & 1.8 & 4.9 & 10.6 & 91 & 27.0 & 538 & 847 & 65 & 1.17 & 0.002 & 2.2 & 32 & 84 & 434 \\
\hline \multicolumn{24}{|c|}{ TowCam } \\
\hline TC2 & sulfide rubble & J2-126-IGT4 & 27 & 48.9 & 6.8 & 1.88 & 457 & 10.6 & 57 & 1.8 & 8.4 & 12.1 & 94 & 25.8 & 536 & 833 & 61 & 1.53 & 0.010 & 1.7 & 33 & 8 & 430 \\
\hline TC2 & sulfide rubble & J2-126-IGT8 & 29 & 48.6 & 6.6 & 1.94 & 456 & 10.6 & 66 & 2.0 & 11 & 12.7 & 93 & 25.6 & 536 & 850 & 62 & 1.92 & 0.005 & 2.8 & 31 & 23 & 422 \\
\hline \multicolumn{24}{|c|}{ ABE } \\
\hline A3 & mussel bed & J2-128-IGT3 & 13 & 51.0 & 7.2 & 2.10 & 456 & 11.1 & 41 & 1.9 & 12 & 10.9 & 94 & 26.9 & 535 & 824 & 64 & 0.64 & 0.004 & 2.7 & 15 & 7 & 431 \\
\hline A3 & mussel bed & J2-128-IGT4 & 11 & 51.7 & 7.4 & 2.15 & 456 & 10.6 & 36 & 1.7 & 10 & 10.9 & 92 & 27.1 & 535 & 829 & 65 & 0.25 & 0.007 & 2.3 & 23 & 14 & 433 \\
\hline A6 & snail bed & J2-129-IGT1 & 18 & 49.5 & 7.0 & 2.11 & 462 & 10.3 & 43 & 2.0 & 15 & 11.2 & 89 & 27.1 & 538 & 833 & 64 & 0.74 & 0.005 & 2.9 & 12 & 5 & 430 \\
\hline A7 & snail bed & J2-129-IGT2 & 101 & 34.7 & 6.1 & 1.34 & 456 & 15.3 & 221 & 7.7 & 122 & 19.3 & 101 & 18.8 & 541 & 873 & 51 & 5.01 & 0.57 & 3.6 & 101 & 31 & 570 \\
\hline \multicolumn{24}{|c|}{ Tu'i Malila } \\
\hline TM3 & mussel bed & J2-132-IGT7 & 32 & 46.6 & 6.5 & 2.06 & 463 & 12.6 & 70 & 5.2 & 73 & 13.7 & 97 & 25.1 & 544 & 830 & 65 & 1.82 & 0.014 & 3.5 & 39 & 23 & 454 \\
\hline TM4 & flange & J2-132-IGT5 & 178 & 26.0 & 5.7 & 1.19 & 480 & 24.9 & 283 & 19.9 & 342 & 28.8 & 129 & 13.88 & 587 & 935 & 49.7 & 7.30 & 0.55 & 7.1 & 169 & 72 & 581 \\
\hline TM9 & snail bed & J2-138-IGT6 & 20 & 48.0 & 6.6 & 2.21 & 469 & 11.6 & 51 & 3.3 & 38 & 12.0 & 95 & 26.4 & 546 & 851 & 62 & 1.74 & 0.001 & & 29 & 20 & 450 \\
\hline \multicolumn{24}{|c|}{ Mariner } \\
\hline MA4 & sph/bar & J2-131-IGT5 & 35 & 25.0 & 3.2 & -0.70 & 444 & 20.8 & 175 & 13.6 & 297 & 25.6 & 103 & 14.2 & 547 & 832 & 87 & 7.83 & 0.089 & 19.1 & 3021 & 1117 & 733 \\
\hline MA4 & sph/bar & J2-131-IGT6 & 59 & 37.6 & 5.1 & 0.50 & 451 & 15.7 & 106 & 8.1 & 163 & 18.6 & 95 & 20.3 & 543 & 829 & 81 & 4.22 & 0.019 & 11.1 & 1587 & 552 & 593 \\
\hline MA7 & sph/bar & J2-135-IGT2 & 48 & 49.9 & 5.9 & 1.72 & 456 & 11.8 & 45 & 2.9 & 41 & 12.5 & 86 & 26.0 & 541 & 837 & 72 & 1.06 & 0.001 & 4.2 & 409 & 198 & 452 \\
\hline \multicolumn{24}{|c|}{ Vai Lili } \\
\hline VLa & microbial mat & J2-133-IGT7 & 40 & 44.8 & 6.5 & 2.01 & 469 & 13.9 & 76 & 5.5 & 75 & 16.0 & 95 & 27.6 & 549 & 839 & 61 & 2.02 & & 2.2 & 358 & 35 & 465 \\
\hline VLa & microbial mat & J2-133-IGT8 & & 45.9 & 6.7 & 2.15 & 467 & 14.0 & 77 & 5.3 & 75 & 15.9 & 96 & 27.7 & 548 & 854 & 65 & 2.05 & & 2.0 & 395 & 32 & 444 \\
\hline VLb & flange & J2-133-IGT3 & 121 & 19.7 & 5.3 & 0.71 & 469 & 28.7 & 239 & 23 & 340 & 23.9 & 91 & 7.7 & 571 & 871 & 21 & 6.14 & 0.010 & & 864 & 80 & 678 \\
\hline VLb & flange & J2-133-IGT4 & 121 & 18.8 & 5.3 & 0.70 & 471 & 28.6 & 237 & 23 & 336 & 23.9 & 91 & 7.7 & 571 & 874 & 20 & 5.24 & 0.007 & & 868 & 81 & 654 \\
\hline VLc & chimney & J2-133-IGT1 & 70 & 13.8 & 5.2 & 0.65 & 474 & 26.8 & 226 & 23 & 311 & 27.6 & 90 & 7.1 & 571 & 878 & 19 & 5.46 & & 8.3 & 991 & 110 & 549 \\
\hline VLc & chimney & J2-133-IGT2 & 70 & 15.0 & 5.2 & 0.77 & 471 & 29.0 & 239 & 21 & 314 & 27.4 & 95 & 7.1 & 572 & 890 & 19 & 5.48 & & & 981 & 98 & 556 \\
\hline VLc & chimney & J2-135-MR & & 17.8 & 5.3 & 0.73 & 469 & 27.4 & 230 & 23 & 315 & 27.7 & 91 & 6.8 & 575 & 870 & 15 & 5.34 & 0.007 & & 955 & 105 & 547 \\
\hline VLc & chimney & J2-135-MG & & 19.5 & 5.3 & 0.44 & 466 & 25.6 & 212 & & & 26.6 & 89 & 8.2 & 570 & 865 & 18 & 5.15 & 0.006 & & 937 & 96 & 554 \\
\hline
\end{tabular}

${ }^{*} \mathrm{~mm}=\mathrm{mmol} / \mathrm{kg}$ fluid, $\mu \mathrm{m}=\mu \mathrm{mol} / \mathrm{kg}$ fluid, $\mathrm{nm}=\mathrm{nmol} / \mathrm{kg}$ fluid.

${ }^{\S}$ Flow type or substrate indicated: sph/bar=sphalerite/barite deposit, VLb flange composed of sulfide+/-sulfate, VLc chimney composed of Fe-oxide. 
Table 4. Water/rock mass ratios calculated from leaching of $\mathrm{Rb}, \mathrm{Cs}$, and $\mathrm{Cl}$ and from Sr isotopic exchange

\begin{tabular}{|c|c|c|c|c|c|c|c|c|c|c|c|c|}
\hline Vent field & $\begin{array}{c}\mathrm{Rb} \\
\text { in rock } \\
(\mathrm{ppm})\end{array}$ & $\begin{array}{c}\mathrm{Rb} \\
\text { in vents } \\
(\mu \mathrm{mol} / \mathrm{kg})\end{array}$ & $\begin{array}{c}\text { Cs } \\
\text { in rock } \\
\text { (ppm) }\end{array}$ & $\begin{array}{c}\text { Cs } \\
\text { in vents } \\
(\mathrm{nmol} / \mathrm{kg})\end{array}$ & $\begin{array}{c}\mathrm{Cl} \\
\text { in rock } \\
(\mathrm{ppm})\end{array}$ & $\begin{array}{c}\mathrm{Cl} \\
\text { in vents } \\
(\mathrm{mmol} / \mathrm{kg})\end{array}$ & $\begin{array}{c}{ }^{87} \mathrm{Sr} /{ }^{86} \mathrm{Sr} \\
\text { in rock }\end{array}$ & $\begin{array}{l}{ }^{87} \mathrm{Sr} /{ }^{86} \mathrm{Sr} \\
\text { in vents }\end{array}$ & $\begin{array}{c}w / r \\
\text { from } R b\end{array}$ & $\begin{array}{c}w / r \\
\text { from Cs }\end{array}$ & $\begin{array}{c}\text { w/r } \\
\text { from } \mathrm{Cl}\end{array}$ & $\begin{array}{l}\mathrm{w} / \mathrm{r} \text { from } \\
{ }^{87} \mathrm{Sr} /{ }^{86} \mathrm{~S}\end{array}$ \\
\hline Kilo Moana & 1.2 & 9.4 & 0.024 & 103 & 500 & 582 & 0.7032 & 0.7045 & 1.7 & 1.8 & 0.3 & 20 \\
\hline TowCam & 2.3 & 8.8 & 0.05 & 113 & 200 & 536 & 0.70319 & 0.7043 & 3.7 & 3.4 & -3.4 & 16 \\
\hline $\mathrm{ABE}$ & 6.2 & 22.2 & 0.13 & 407 & 800 & 563 & 0.70326 & 0.7042 & 3.5 & 2.4 & 0.9 & 17 \\
\hline Tui Malila & 8.1 & 46.6 & 0.17 & 822 & 1100 & 648 & 0.70319 & 0.7038 & 2.1 & 1.6 & 0.3 & 12 \\
\hline Mariner & 8.1 & 30.4 & 0.17 & 697 & 1200 & 582 & 0.70330 & 0.7042 & 3.3 & 1.8 & 0.8 & 15 \\
\hline Vai Lili (2005) & 8.1 & 32.0 & 0.17 & 496 & 1200 & 596 & 0.70325 & 0.7055 & 3.1 & 2.6 & 0.6 & 34 \\
\hline Vai Lili (1989) & 8.1 & 64.7 & 0.17 & 1330 & 1200 & 769 & 0.70320 & 0.7044 & 1.5 & 1.0 & 0.1 & 20 \\
\hline
\end{tabular}

Bottom seawater: $\mathrm{Rb}=1.4 \mu \mathrm{mol} / \mathrm{kg}, \mathrm{Cs}=2.3 \mathrm{nmol} / \mathrm{kg}, \mathrm{Cl}=538 \mathrm{mmol} / \mathrm{kg},{ }^{87} \mathrm{Sr} /{ }^{86} \mathrm{Sr}=0.7091$

$\mathrm{Rb}$ and $\mathrm{Cs}$ in rock based on data for Lau Basin glasses from PetDB (Lehnert et al., 2000) and from Bezos et al. (2009).

Data on $\mathrm{Cl}$ and ${ }^{87} \mathrm{Sr} /{ }^{86} \mathrm{Sr}$ in rock are from P. J. Michael. 


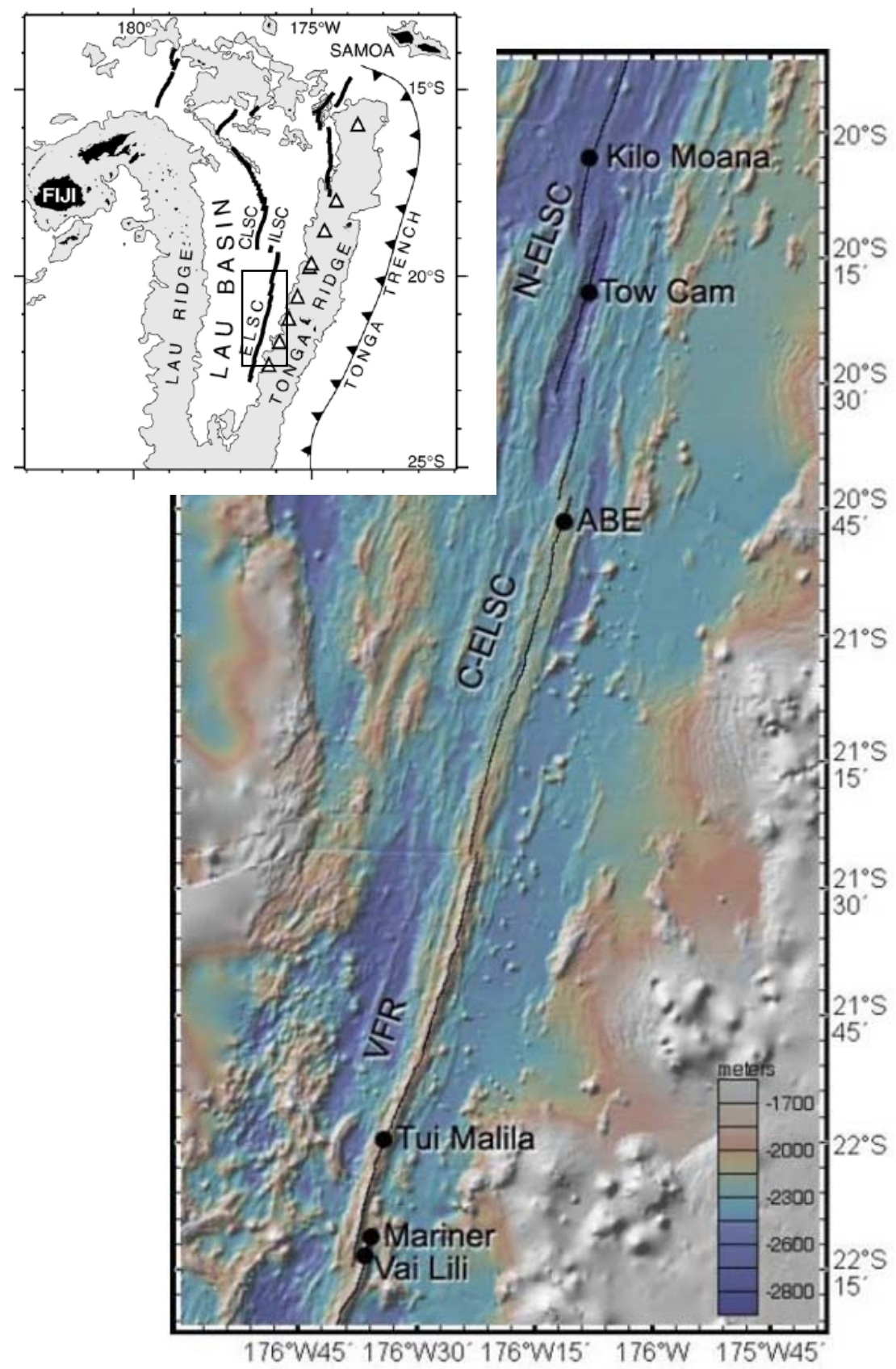

Fig. 1 


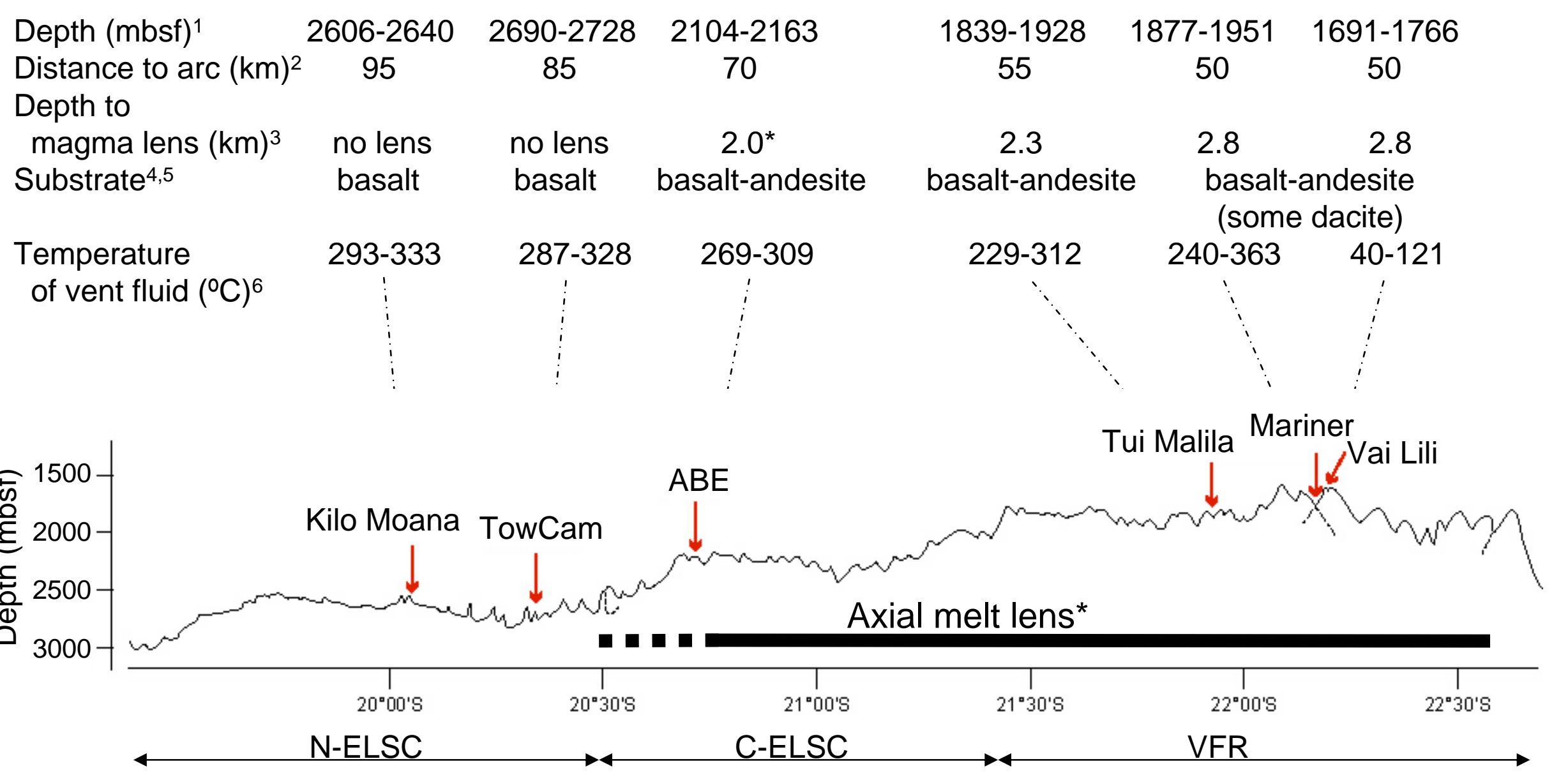

References: 1) Ferrini et al. (2008), 2) Martinez et al. (2002), 3) Jacobs et al. (2007), 4) Michael and Seewald (2007), 5) Fouquet et al. (1993), 6) this paper.

*Ref. 3 notes that dashed line of axial melt lens is "nearly continuous" versus "continuous" to south; Lau ISS workshop report (2006) notes "Our initial analyses show that all three explored ELSC vent fields, Kilo Moana, Tow Cam, and ABE, lack areas of nearly pure melt directly beneath them. However, several areas of nearly pure melt lie beneath the southern end of the spreading segment just northwest of the ABE site."

Fig. 2 


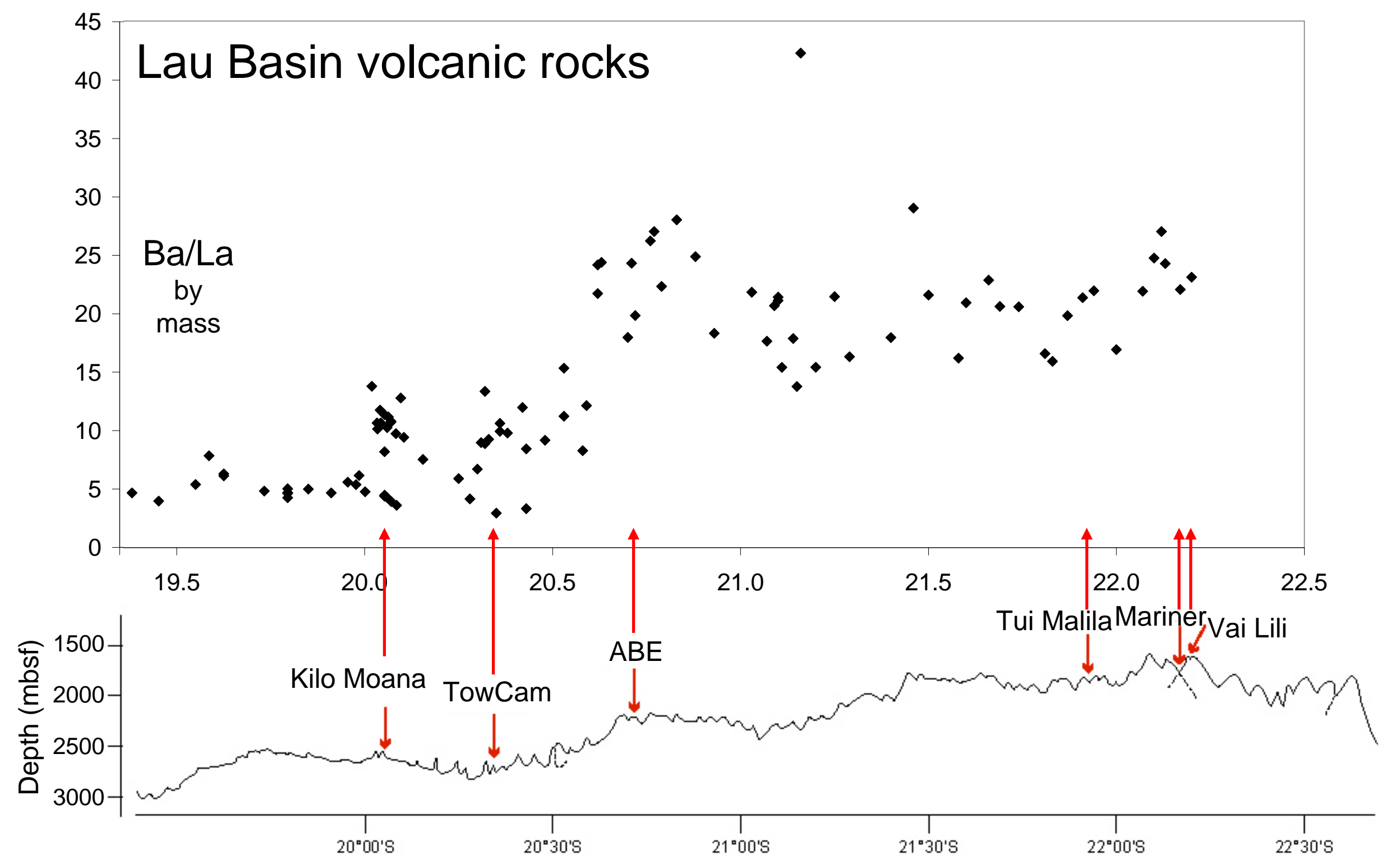

Fig. 3 

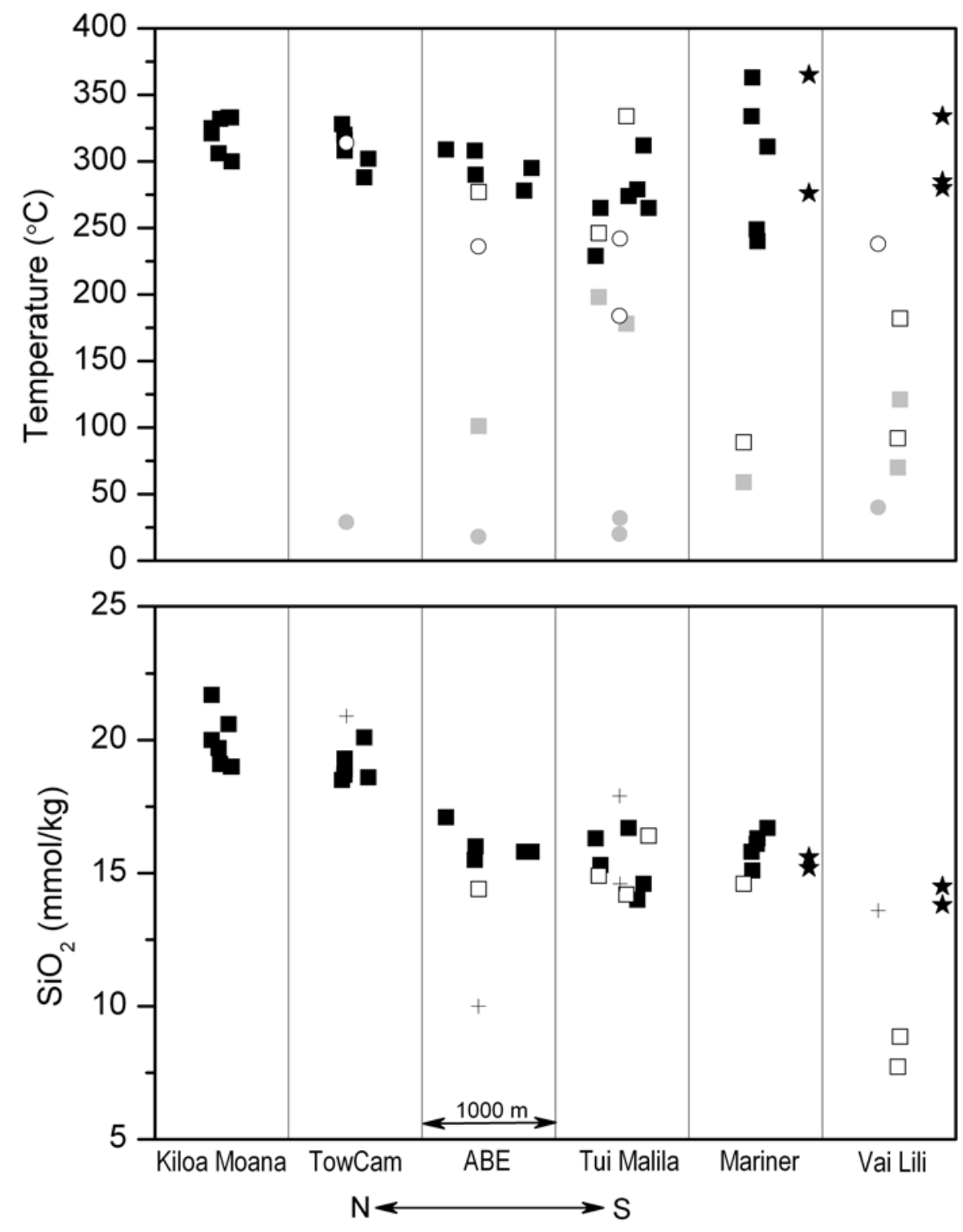

Fig. 4 


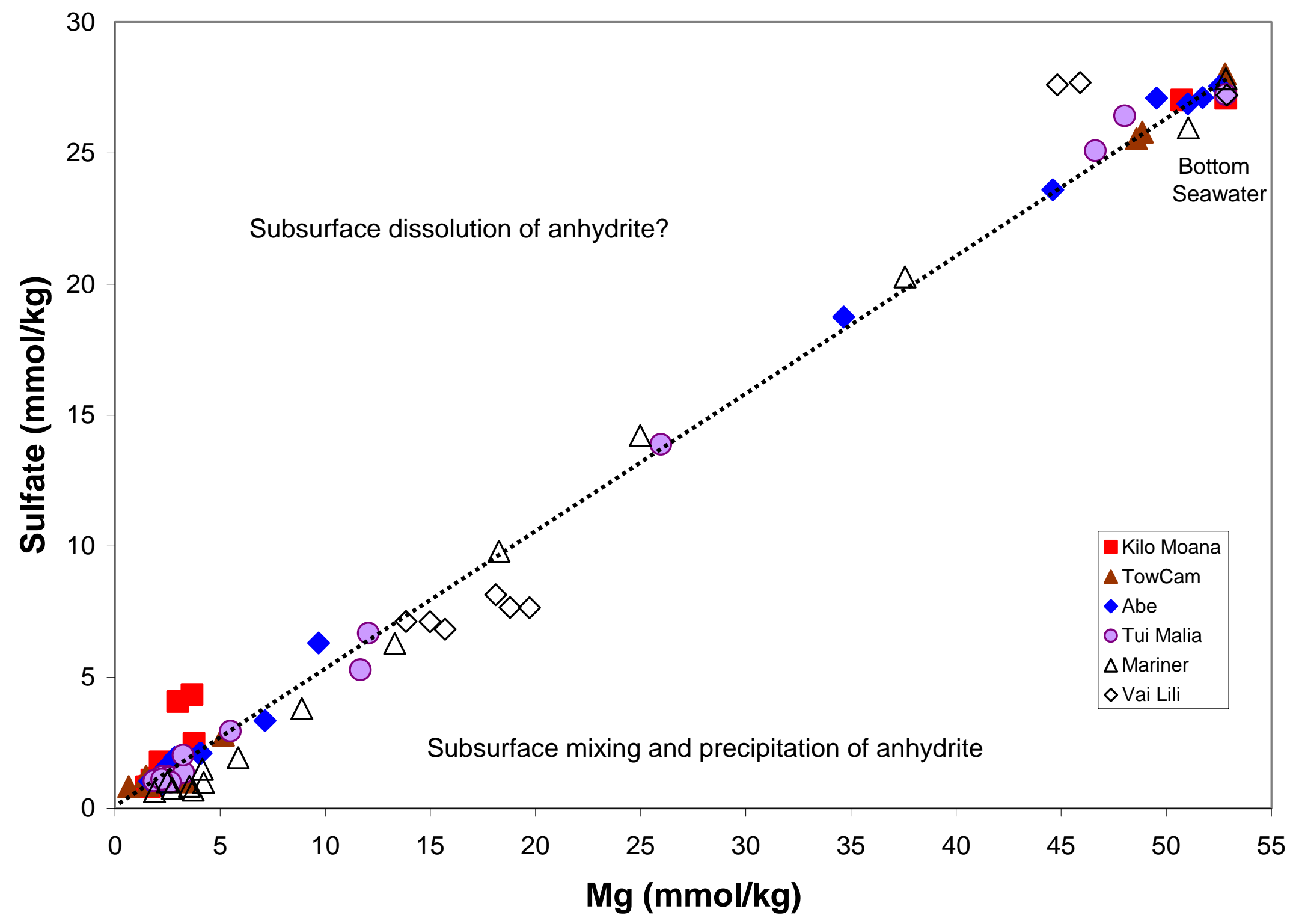

Fig. 5 

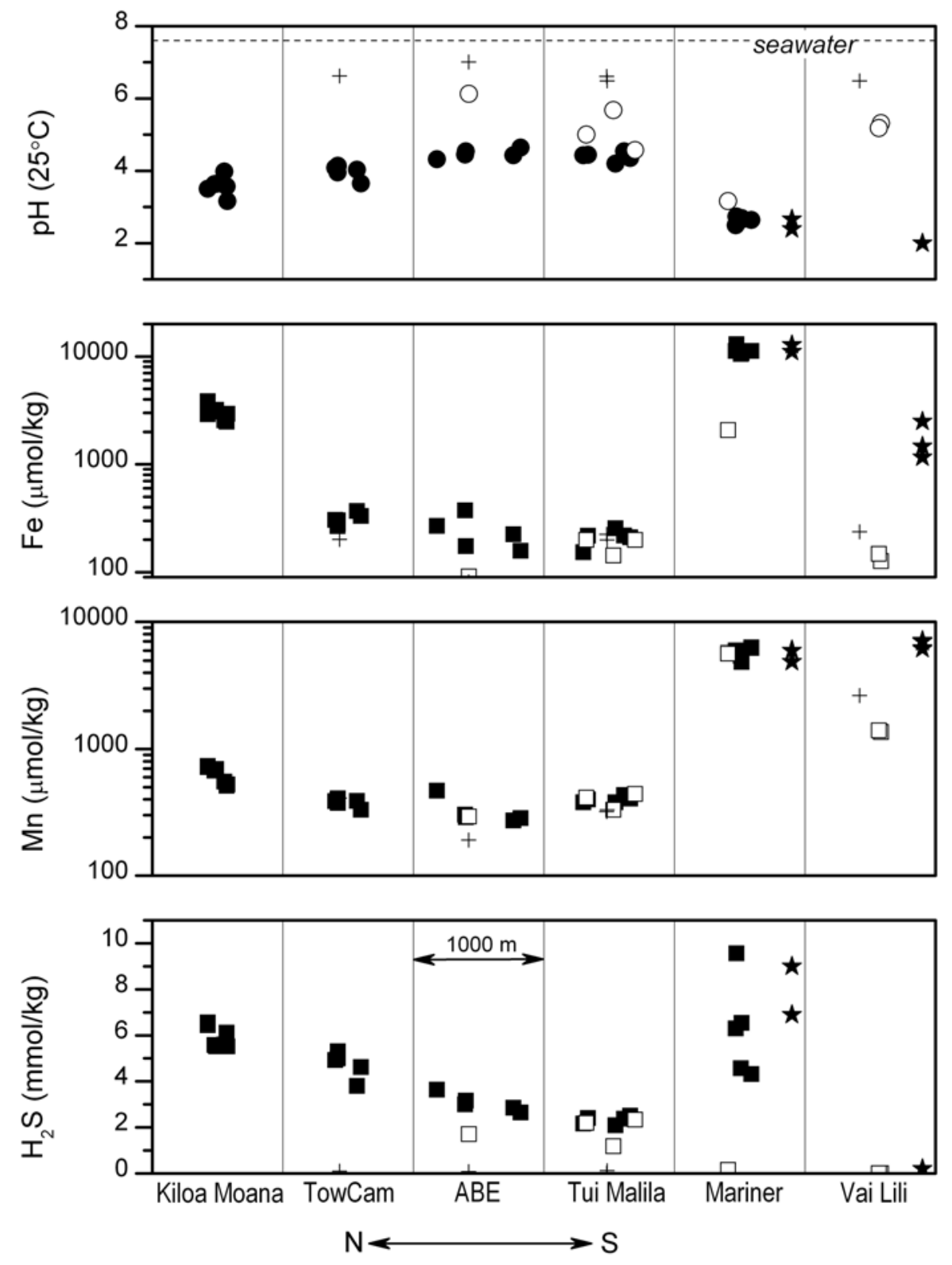

Fig. 6 

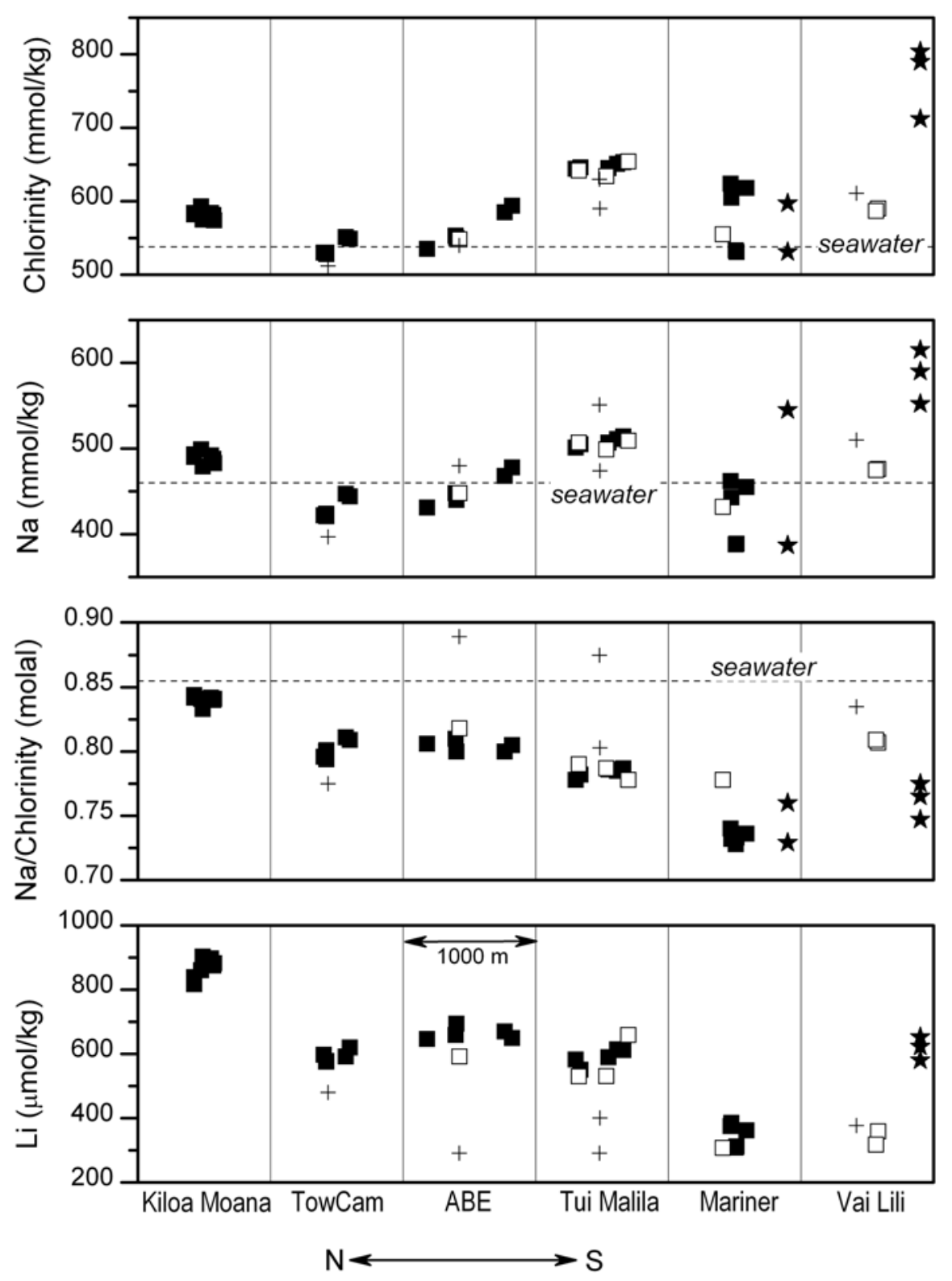

Fig. 7 

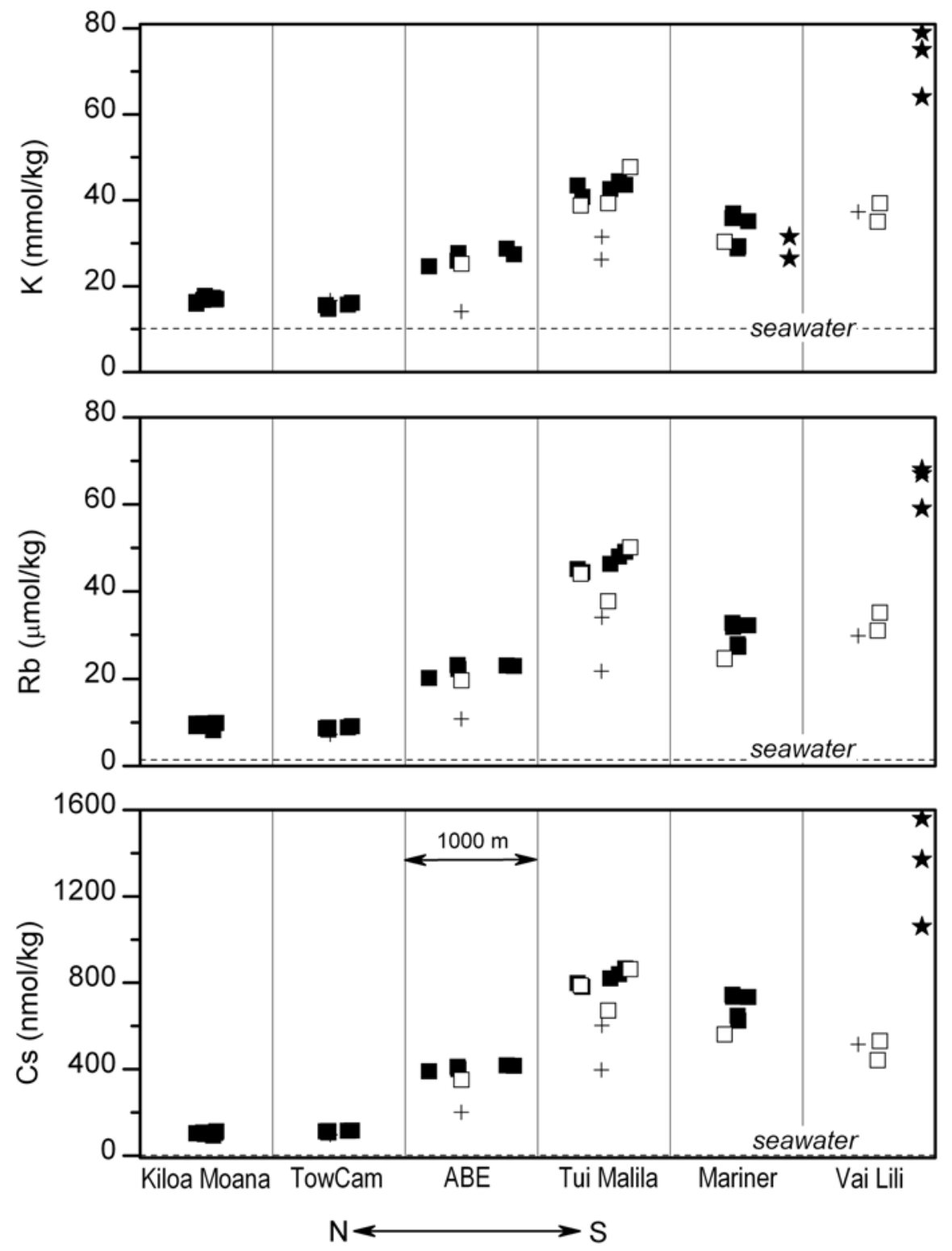

Fig. 8 

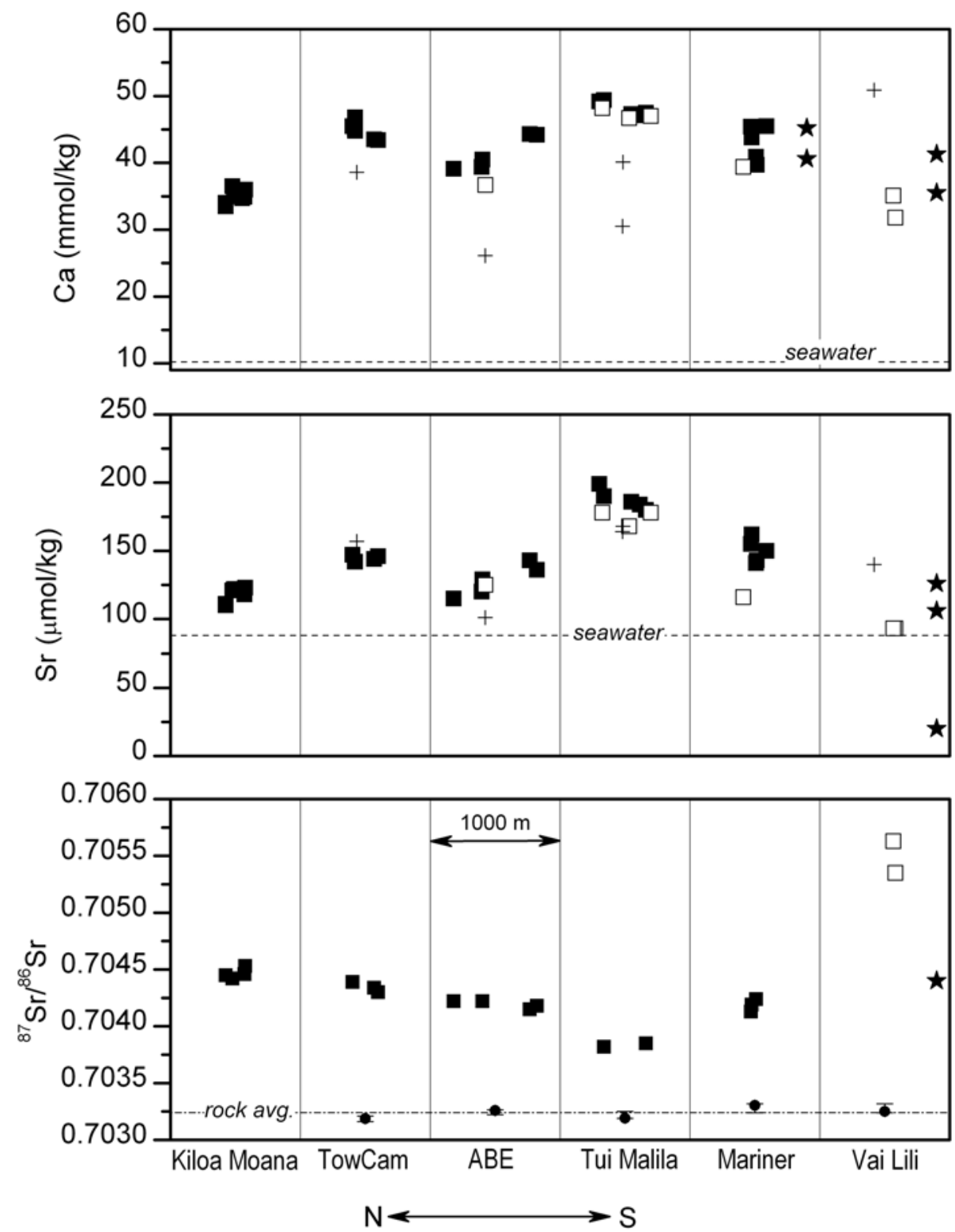

Fig. 9 

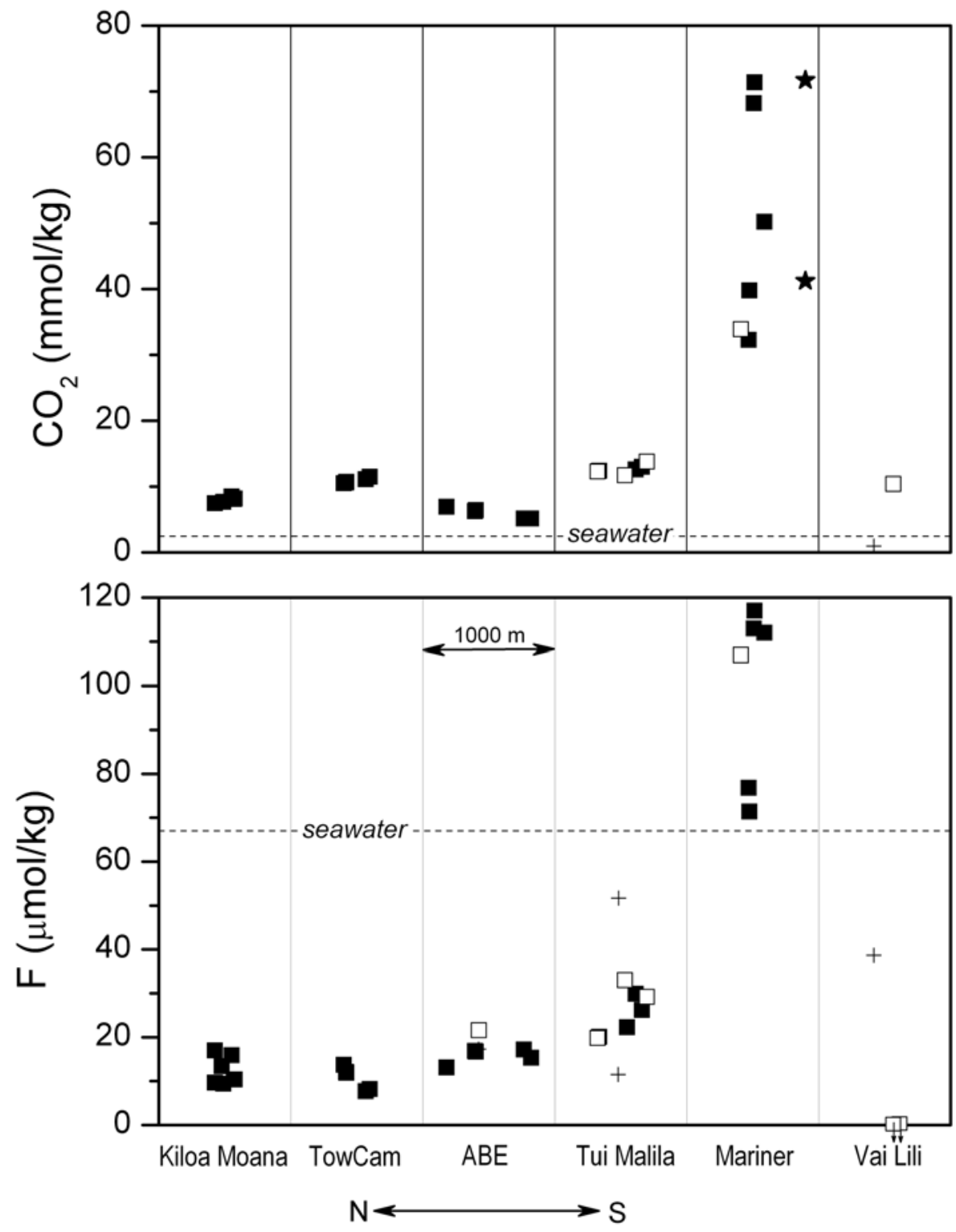

Fig. 10 

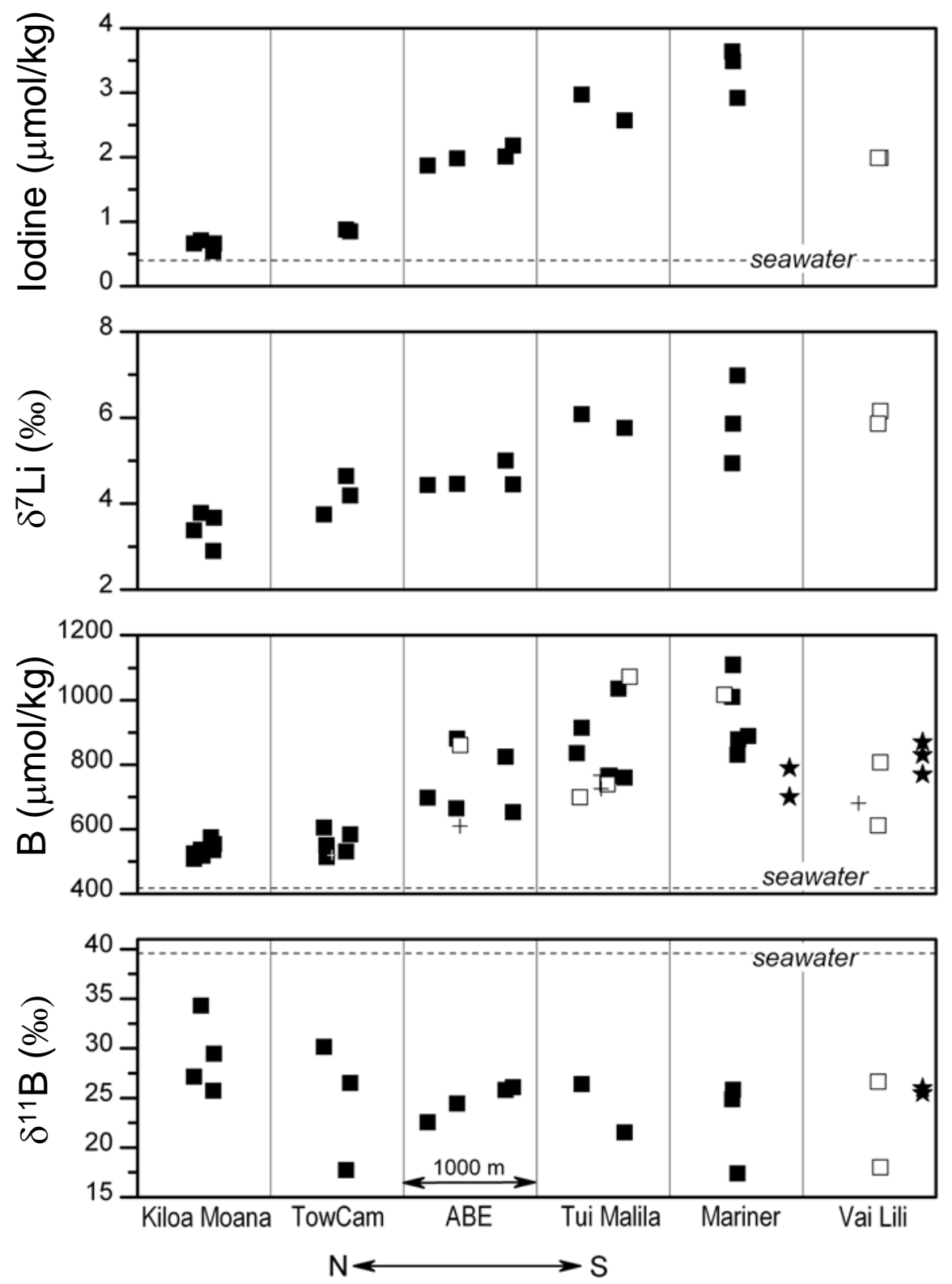

Fig. 11 


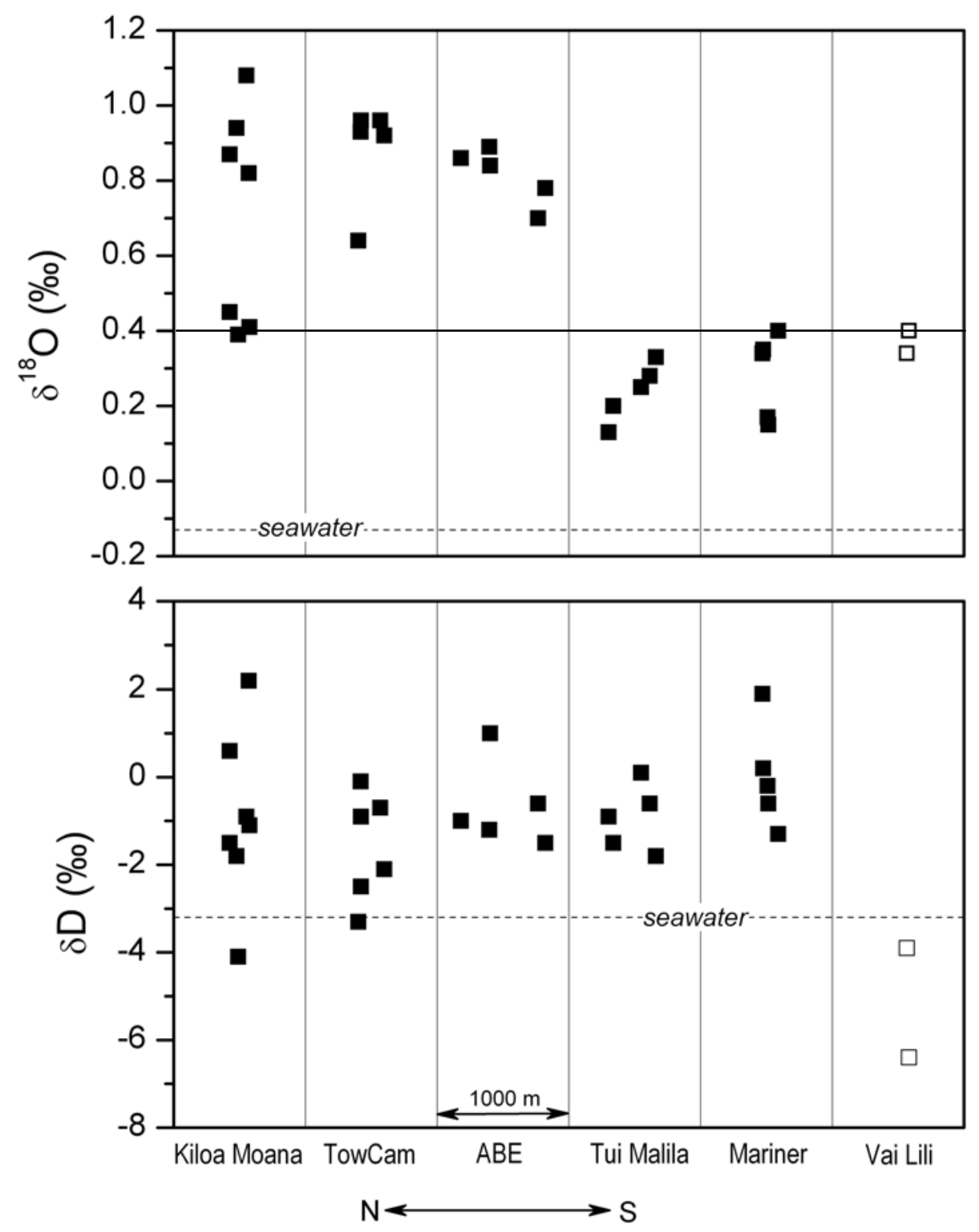

Fig. 12 

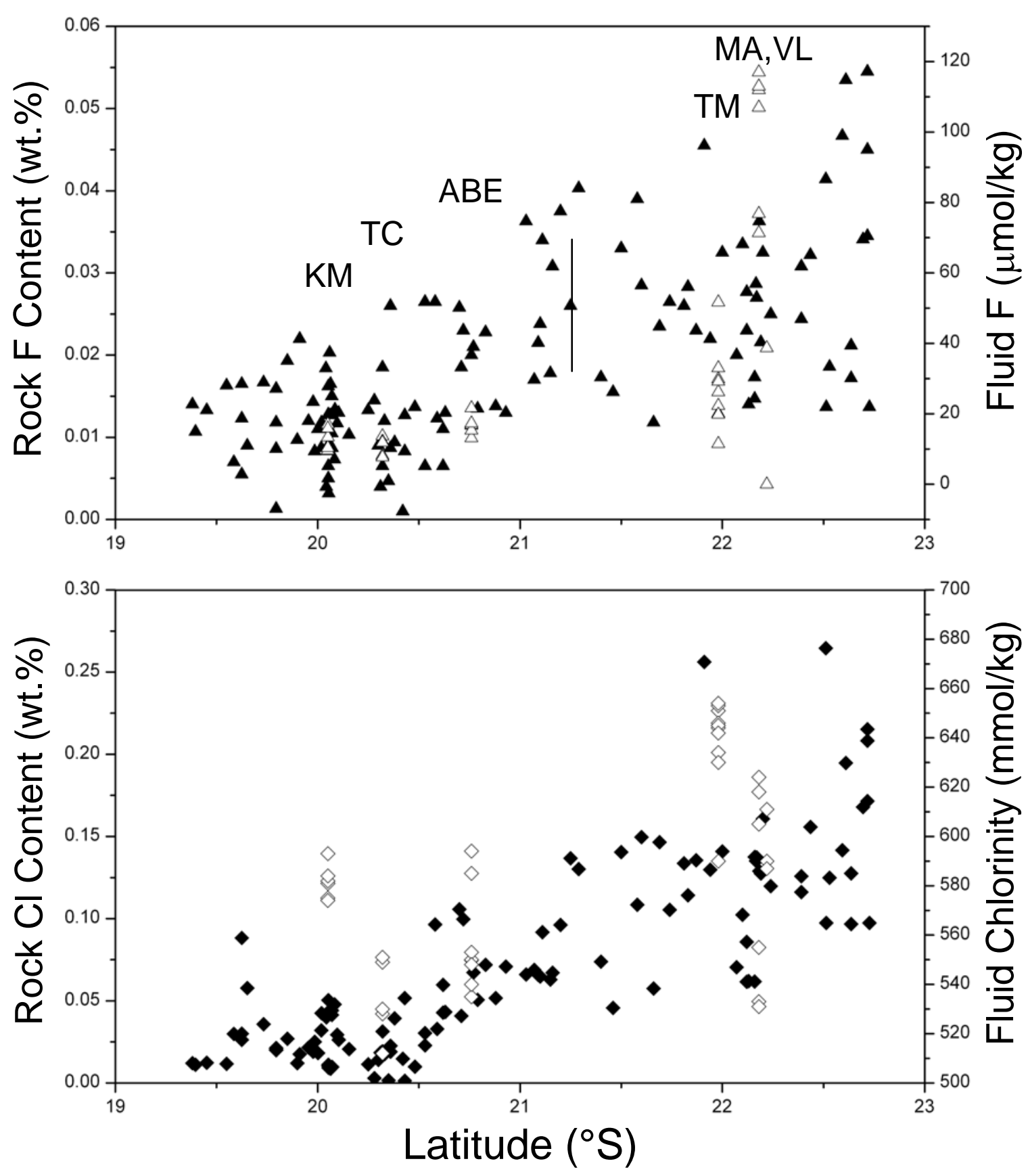

Fig. 13 


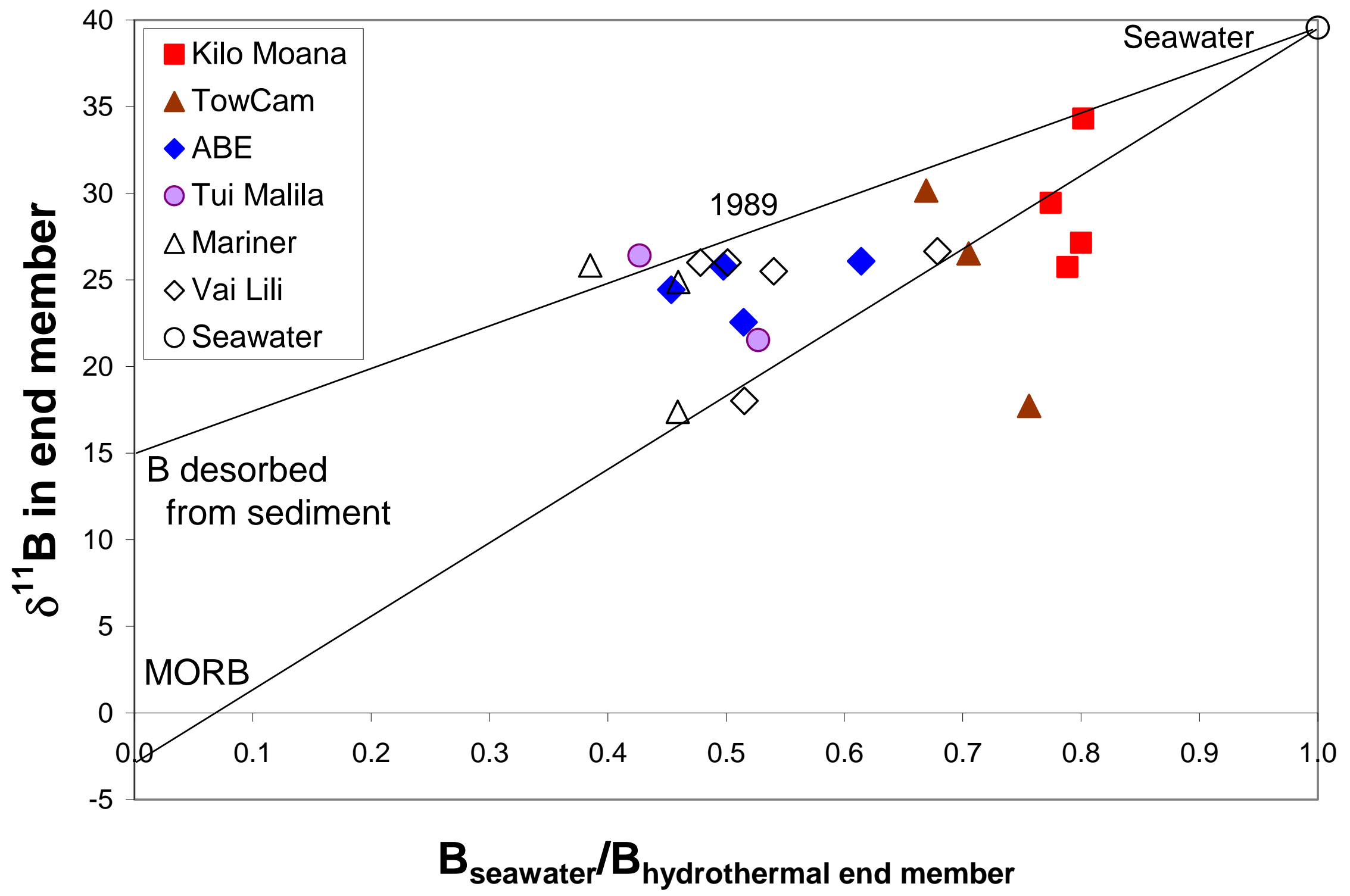

Fig. 14 

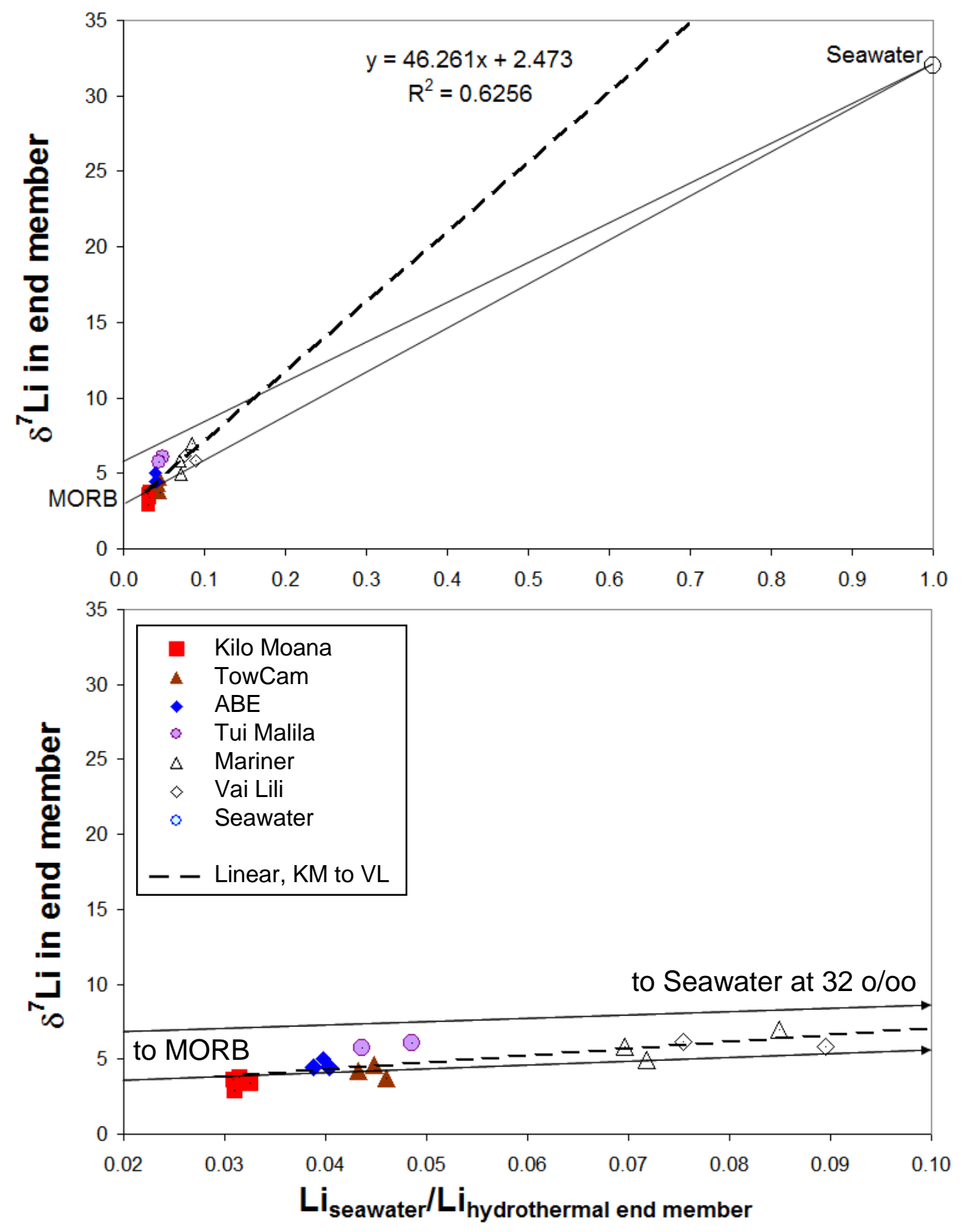


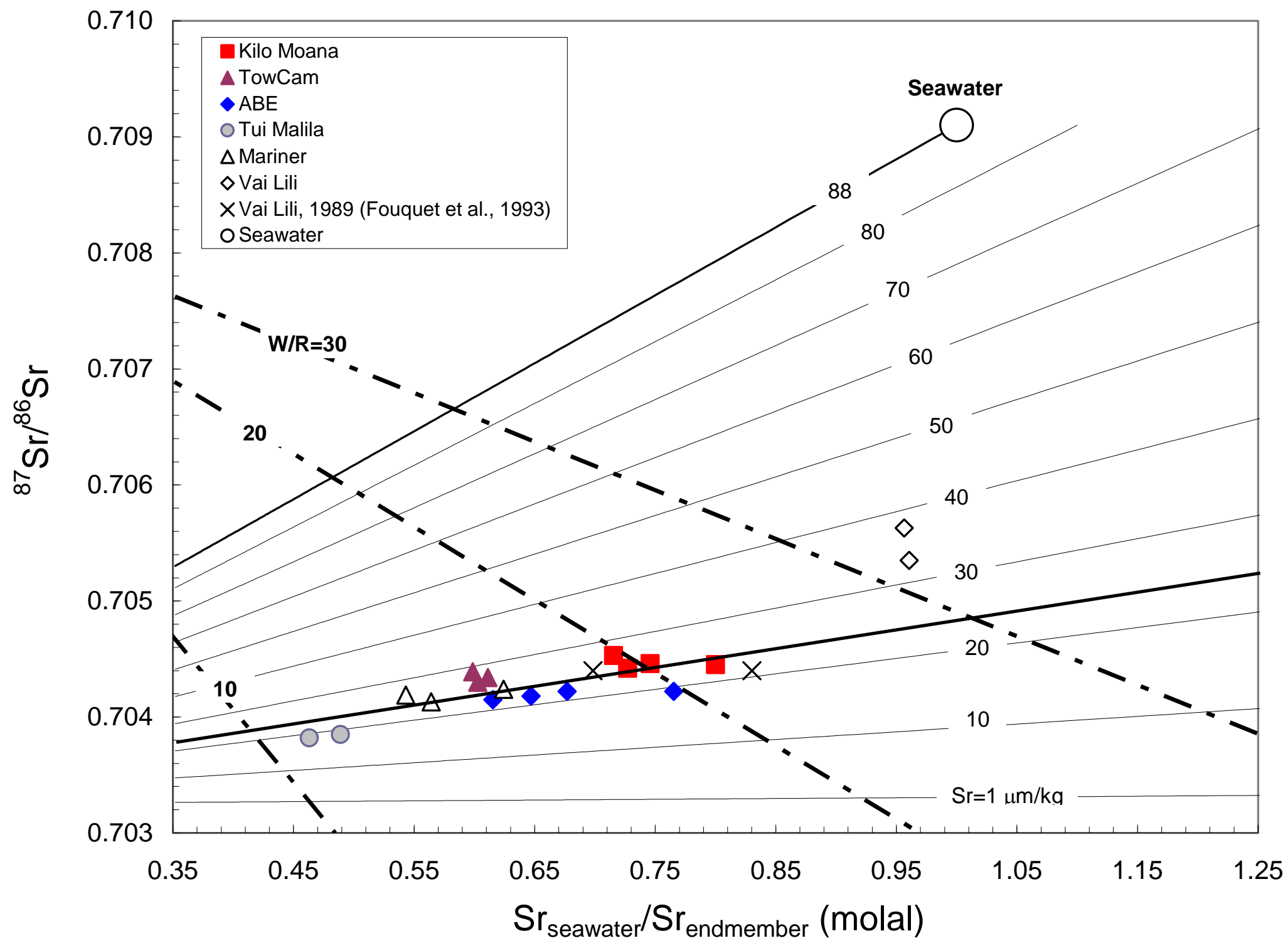

Fig. 16 